\title{
Well records on the
}

\section{Phanerozoic stratigraphy in the Fennoscandian Border Zone, Denmark}

Hans-1, Sæby-1, and Terne-1 wells

By

OLAF MICHELSEN \& LARS HENRIK NIELSEN

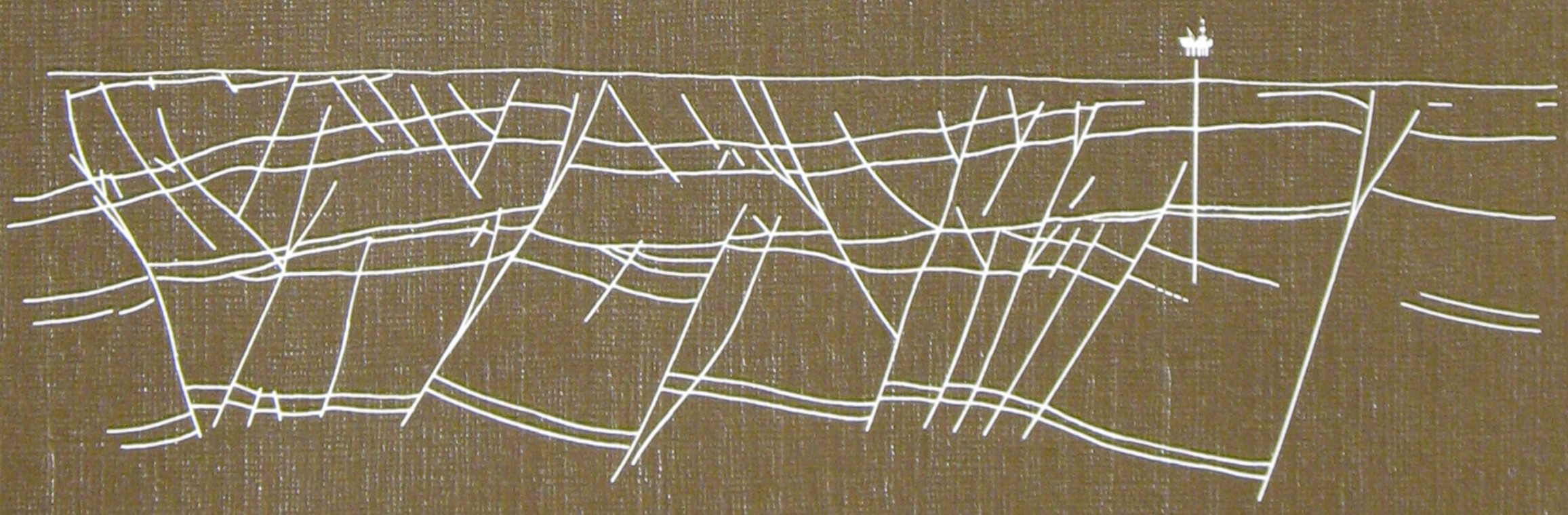

Danmarks Geologiske Undersøgelse · København 1991 


\section{Well records on the Phanerozoic stratigraphy in the Fennoscandian Border Zone, Denmark}

Hans-1, Sæby-1, and Terne-1 wells

By

OLAF MICHELSEN \& LARS HENRIK NIELSEN

Danmarks Geologiske Undersøgelse · København 1991 
Key words: Fennoscandian Border Zone, Sorgenfrei-Tornquist Zone, Skagerrak-Kattegat Platform, structural evolution, stratigraphy, Palaeozoic, Upper Carboniferous, Permian, Mesozoic, volcanic rocks.

Vignette: A SW - NE geo-section of the Sorgenfrei - Tornquist Zone through the Hans -1 well.

DGU Serie A nr. 29

ISBN 87-88640-69-8

ISSN 0901-0270

Oplag: 1000

Tryk: AiO Tryk as, Odense

Tegninger: Eva Melskens

Dato: 31.10.1991

Olaf Michelsen,

Geological Institute, University of Aarhus, C. F. Møllers Allé,

DK-8000 Århus C, Denmark

Lars Henrik Jensen,

Geological Survey of Denmark,

Thoravej 8, DK-2400 København NV, Denmark.

Redaktion: Leif Banke Rasmussen

(C) Danmarks Geologiske Undersøgelse,

Thoravej 8, DK-2400 København NV

I kommission hos: Geografforlaget ApS.

Ekspedition: Fruerhøjvej 43, 5464 Brenderup

Telefon: 64441683 


\section{Contents}

Abstract $\ldots \ldots \ldots \ldots \ldots \ldots \ldots \ldots \ldots \ldots \ldots$

Introduction . . . . . $\ldots \ldots \ldots \ldots \ldots \ldots \ldots$

Geological setting .............. 5

Material and methods ............. 5

Well descriptions ................. 7

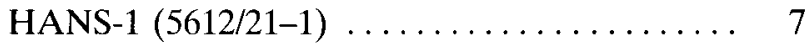

Lithology and lithostratigraphy ........ 7

Chronostratigraphy............... 10

SÆBY-1 (5710/22-1) . . . . . . . . . . 13

Lithology and lithostratigraphy ......... 13

Chronostratigraphy............... 18

TERNE-1 (5611/23-1) .............. 20

Lithology and lithostratigraphy ........ 20

Chronostratigraphy.............. 24



Lower Palaeozoic . . . . . . . . . . . . . . . . 29

Stratigraphic correlation . . . . . . . . . . . 29

Thickness distribution $\ldots \ldots \ldots \ldots \ldots \ldots . . .30$

Upper Palaeozoic ................. 30

Mesozoic...................... 31

Palaeogeographic aspects. . . . . . . . . 32

Early Palaeozoic .................. 32

Late Palaeozoic ................. 33

Mesozoic..................... 34

Conclusions .................... 35

Acknowlegments ................. 36

References ..................... 37 


\section{Abstract}

The Hans-1, Sæby-1, and Terne-1 wells are located within the Danish part of the Fennoscandian Border Zone and provide significant new data pertaining to the evolution of this important tectonic belt. All three wells encountered Palaeozoic rocks; the Terne-1 well extended into the lower Palaeozoic. Two of the wells are located in the Danish waters of the Kattegat, and thus yield the first deep well data from this part of the border zone.

The wells encountered Cambrian to Silurian, Carboniferous to Zechstein and Triassic to Upper Cretaceous successions. The Cambrian to Lower Silurian section is interpreted to represent shelf and shallow marine deposits comparable to those known from Scania and Bornholm. The inferred Upper Silurian section is calculated to be up to $2600 \mathrm{~m}$ thick and may represent the fill of a foreland basin in front of the Caledonian deformation front. A hiatus comprising the Devonian to Lower Carboniferous is inferred. A $550 \mathrm{~m}$ thick Rotliegende sequence was drilled in the eastern part of the Sorgenfrei-Tornquist Zone; changes in structural dip indicate a syn-depositional faulting. Palaeozoic tectonism is also indicated by Late Carboniferous intrusive and extrusive volcanic rocks. Reworked volcanic rocks characterize the Rotliegende clastic sequence. A thin siliciclastic Zechstein sequence is recognized.

The lithology and stratigraphy of the Mesozoic sections are in accordance with well data from the Danish Subbasin. The presence of a Middle Jurassic depocenter within the Sorgenfrei-Tornquist Zone may indicate a tectonically controlled subsidence of the zone. The occurrence of a Late Cretaceous to Early Tertiary inversion tectonism is supported by these new data. 


\section{Introduction}

The Kattegat region has previously only been known from geophysical data, and published models of basin development through geological time have mainly been based on seismic data and data from the adjacent onshore areas. Thus, the primary goals of this paper are 1) to interpret the data available from 3 newly released wells located within the Danish part of the Fennoscandian Border Zone and 2) to describe the dynamic stratigraphic development of the zone during the Phanerozoic. Palaeogeographic aspects will also be discussed, using supporting data from adjacent onshore areas.

Basinal development of the Kattegat region have been dealt with in a large number of publications. A comprehensive review is, therefore, outside the scope of this paper; a brief description of the structural setting and regional evolution is given below.

\section{Geological setting}

The Kattegat region is transected by a strongly faulted zone that separates the Fennoscandian Shield to the northeast from the Norwegian-Danish Basin to the west and southwest. This zone was named the Fennoscandian Border Zone by Sorgenfrei \& Buch (1964), who described it briefly as a strongly block-faulted northwest-southeast trending zone. The Kattegat region was mapped seismically for the first time by Baartman \& Christensen (1975).

The zone has subsequently been regarded as a northwesterly extension of the Tornquist Zone, which forms a continuous fault zone from the Black Sea to the central North Sea (Pegrum 1984, Bergström 1984). Pegrum argued that the zone was a Precambrian zone of weakness, that subsequentially experienced strike-slip movements during the Variscian phase. Triassic and Jurassic extensional tectonics and compression during the Cretaceous and Tertiary are also considered. Bergström (1984) proposed that the thick Upper Silurian deposits of the Colonus Shale Trough, which forms part of the Fennoscandian Border Zone in Scania, probably did not extend farther northeastwards, indicating that the present trough-like structure was a syn-depositional feature.

The most recent discussion was presented by Liboriussen et al. (1987) and the EUGENO-S Working Group (1988). Liboriussen et al. (1987) considered the Fennoscandian Border Zone a continuation of the
Tornquist Zone and proposed it has been tectonically active from early Palaeozoic to recent times. Important tectonic phases proposed by the workers were tensional early Palaeozoic tectonics, late Palaeozoic dextral wrench movements, Triassic to Early Cretaceous transtensional and Late Cretaceous to Early Cenozoic transpressional structures.

The EUGENO-S Working Group (1988) considered the structural line through the Kattegat region as being a discrete structural element rather than an integrated part of the Tornquist Zone. It was termed the Sorgenfrei-Tornquist Zone, whereas the Polish-Ukrainian element was referred to as the Teisseyre-Tornquist Zone (fig. 1). The Sorgenfrei-Tornquist Zone cuts through the Precambrian crustal province, whereas the Teisseyre-Tornquist Zone follows the southwestern boundary of the province. The two zones converge at the Rønne Graben, offshore Bornholm. The SorgenfreiTornquist Zone is defined as a strongly faulted zone primarily characterized by Late Cretaceous to Tertiary inversion tectonics. The area between this zone and the Fennoscandian Shield was named the Skagerrak-Kattegat Platform (fig. 1), which is characterized by eastwards thinning and relatively undisturbed Mesozoic and Cenozoic sequences.

In this paper, we follow the definitions of the structural units as described by the EUGENO-S Working Group (1988). The term Fennoscandian Border Zone will, however, be used for the structural region comprising the Sorgenfrei-Tornquist Zone and the Skagerrak-Kattegat Platform (fig. 1).

Two of the studied wells, Hans-1 and Terne-1, are located offshore in the Kattegat within the SorgenfreiTornquist Zone. The third well, Sæby-1, is located in North Jylland, but still within the Skagerrak-Kattegat Platform (fig. 1).

\section{Material and methods}

Well data from the Hans-1, Sæby-1, and Terne-1 wells, together with relevant seismic lines, form the basis of this study. The well data comprise petrophysical measurements $(\operatorname{logs})$, cuttings samples, sidewall cores, well cores, and reports presented by the oil companies or commercial service companies. 


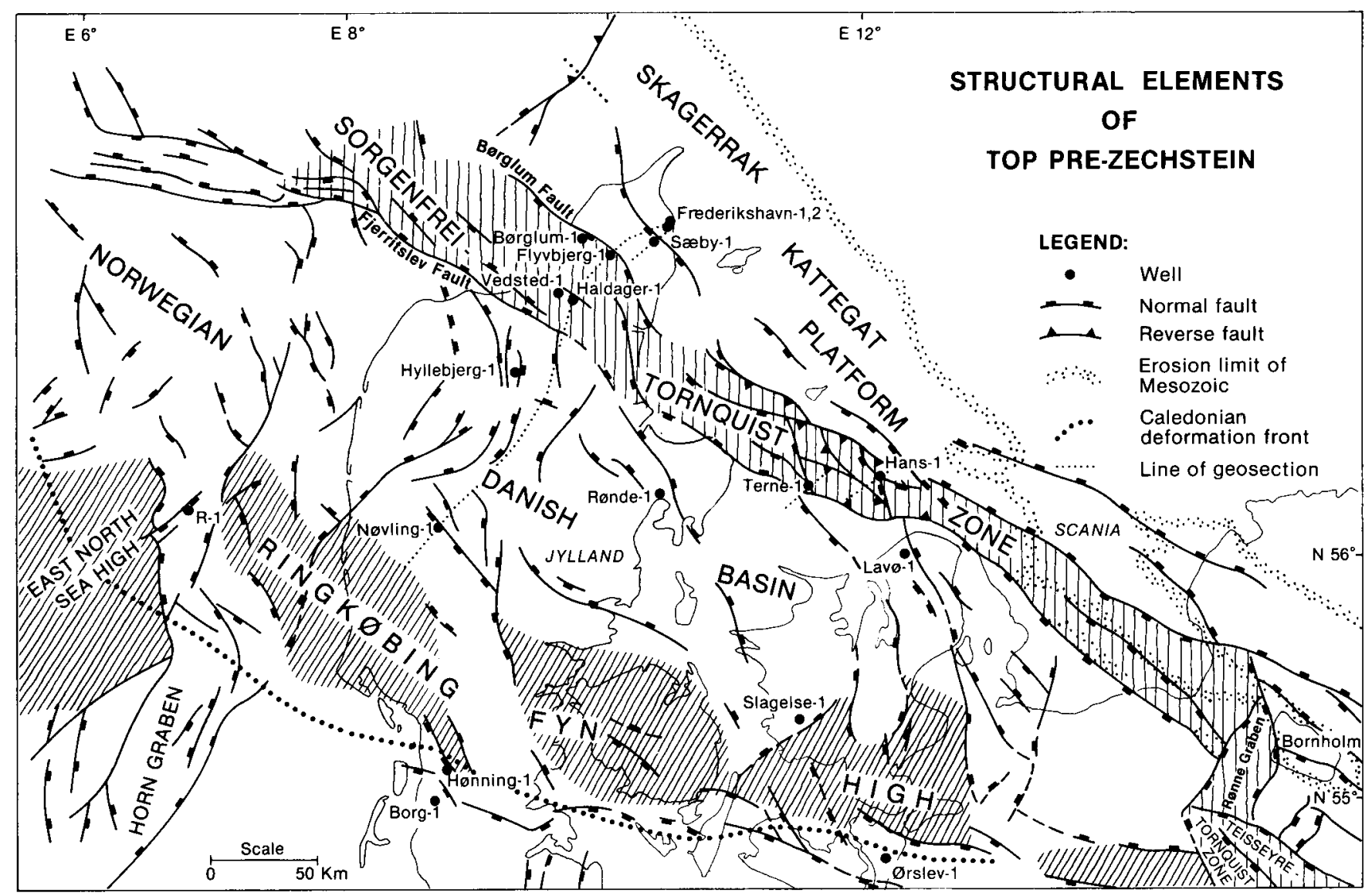

Figure 1: Map of general structural elements at top pre-Zechstein level. Modified from EUGENO-S Working Group (1988) and Vejbæk (1990, based on work by Claus Andersen, DGU). Locations of wells and seismic profiles are shown.

The gamma ray and sonic logs, together with neutron-density logs and resistivity logs, have been used for the identification of lithostratiphic units and for the description of the lithology in connection with the cuttings samples, sidewall cores, and cores. The lithostratigraphic correlation is based on gamma ray and sonic logs; the gamma ray log has also been used to provide a tentative chronostratigraphic correlation of the lower Palaeozoic sequences.
The company reports used here are primarily concerned with biostratigraphy, but descriptions of the lithology have also been included, especially those based on sidewall cores. Biostratigraphic studies have not been carried out by the authors. We have concentrated on interpretation of lithology, stratigraphy, and structural features. 
In this section the pre-Quaternary sequence encountered in the three wells, Hans-1, Sæby-1, and Terne-1, is described (see figs 1 and 2). The lithology and the lithostratigraphy is based on interpretation of the petrophysical logs and the lithological sample descriptions. Cores and cutting samples were studied at certain intervals to clarify discrepancies between log-analysis and lithological descriptions. The chronostratigraphic subdivision is partly based on biostratigraphic analyses, and partly on correlations to older wells located in the basin. All depth figures given below are related to either kelly bushing (KB), drilling floor (DF), or rotary table (RT) on the drilling rig or the mean sea level (MSL).

\section{HANS-1 (5612/21-1)}

Locality: $56^{\circ} 21^{\prime} 55^{\prime \prime} \mathrm{N}, 12^{\circ} 00^{\prime} 51^{\prime \prime} \mathrm{E}$.

Elevation: Ground (sea floor) $30.3 \mathrm{~m}$ b.MSL, KB 23,5 $\mathrm{m}$ a.MSL.

\section{Lithology and lithostratigraphy}

Well-bedded sandstone, siltstone, and claystone, 303.5 (TD)-2777 m b.KB, 3008-2753.5 m b.MSL:

The interval is characterized by relatively high, highly variable gamma ray values and high, fairly constant sonic velocities. The log-patterns reflect a succession of sandstone, siltstone, and claystone, interbedded on a scale of a few metres; according to the cuttings samples, typical colours are red, reddish brown, greenish, and white. A core $5.5 \mathrm{~m}$ long from the lower part comprises medium to fine-grained, well sorted, greyish red and green sandstone (fig. 3). The micro-resistivity logs also reflect the well-bedded nature of the sequence, and the dipmeter log shows very well-defined dips with an average value of $24^{\circ}$ towards the eastnortheast. The upper boundary is clearly marked by a pronounced decrease in gamma ray values, a negative separation of the neutron-density readings, and poorly defined dip data, indicating the boundary between this clastic sequence and the overlying volcanic series.
Volcanic rocks and claystones, 2777-2454 m b.KB, 2753.5-2430.5 m b.MSL:

This interval is readily subdivided into 2 distinct portions, a lower unit of volcanic rocks and an upper unit of claystones. There is a clear log-break at $2535 \mathrm{~m}$, indicating the boundary between these two units. The upper boundary of the interval is located at the base of the overlying coarse-grained sequence, indicated by a decrease in gamma ray values. The volcanic series consists of basalt layers and thin siltstone beds. The logpattern indicates a dominance of massive basalt layers in the upper part of the volcanic series. The sonic velocity and the resistivity logs show clearly upward decreasing trends, indicating that the upper part of several basalt layers are weathered, which suggests that the volcanic rocks were extrusives. The overlying deposits consist of red claystone interbedded with thin sandstone and siltstone beds. In general, the interval yields poor dip data, but reliable data from the uppermost part of the volcanic sequence and the lower part of the claystone sequence indicate a dip of $22-24^{\circ}$ towards the east.

Rotliegende Group, 2454-1903 m b.KB, 2430.51879.5 m b.MSL:

This interval is characterized by uniform low gamma ray values, positive separation of the neutron-density curves, and uniform high sonic velocities. The upper boundary is located at the top of this uniform interval. The gamma ray values show general increase above the boundary, indicating an increased clay content.

The cuttings samples suggest the occurrence of conglomerates and poorly sorted sandstones with angular pebbles and grains predominantly consisting of volcanic rock fragments and redbrown to grey siltstone fragments. The log-pattern indicates the presence of a densely cemented sequence of volcaniclastic rocks in the upper $350 \mathrm{~m}$ and in the lowermost $25 \mathrm{~m}$, separated by a sequence that includes clay- and siltstone interbeds. The dipmeter shows fairly good data indicating a gradual decrease in dip from an average value of $20-24^{\circ}$ in the lowermost part of the interval to a value of approximately $4-6^{\circ}$ towards the east-northeast in the uppermost part. 


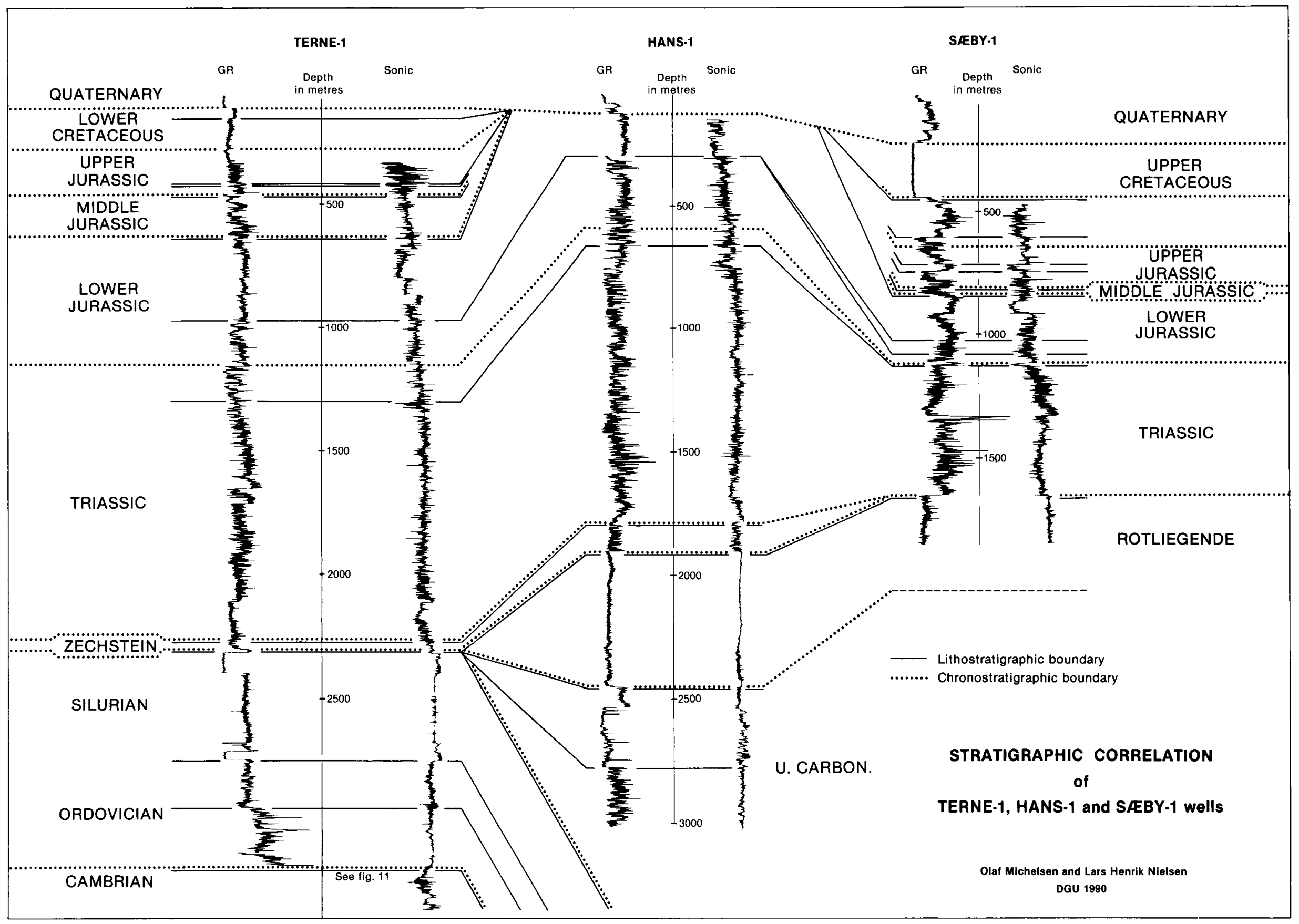

Figure 2: Stratigraphic correlation of the Hans-1, Sæby-1 and Terne-1 wells. 


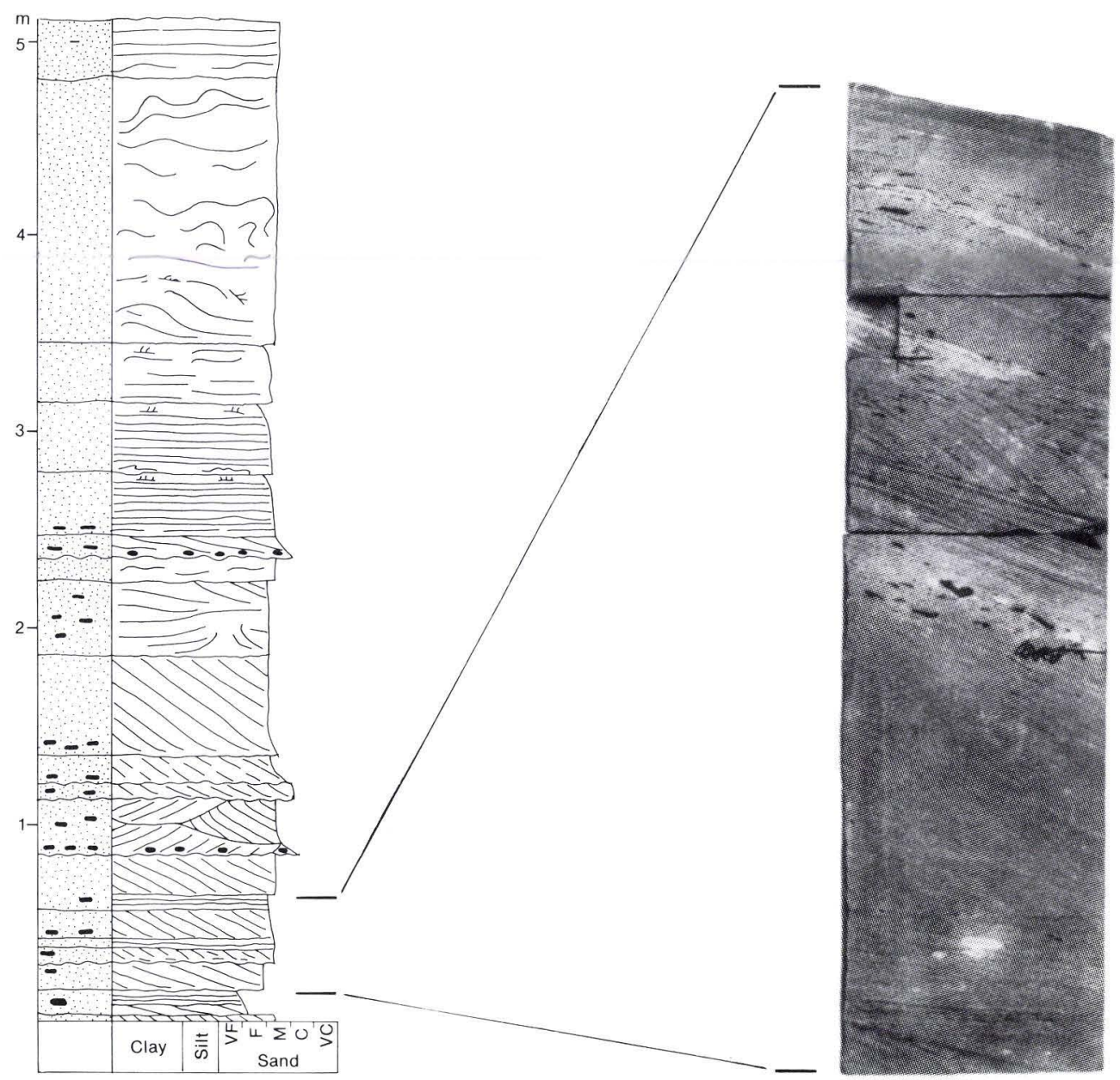

Figure 3:

Well: Hans-1

Core 1: 3005.00-3009.85 m b.KB

Description: Sandstone, medium to fine-grained, well sorted, mainly reddish grey, occasionally olive green, micaceous, non to slightly calcareous, hard, low visible porosity. Abundant platy and rounded, redbrown and green claystone clasts, with sizes up to 6 $\mathrm{cm}$. Most common at lower set-boundaries. The sandstone is cross-bedded with some parallel laminated and cross-laminated intervals. The stratification is intensely disturbed in large parts of the core. Apparent dip is approximately $24^{\circ}$.

Interpretation: The cross-bedding indicates megaripple migration driven by fairly high energy, unidirectional currents possibly within channels. The abundant platy claystone clasts indicate important local reworking of clay beds. The alternation of intervals showing of cross-bedding, parallel-lamination and the occurrence of clay beds indicate fluctuating flow strength. The dominant reddish colour indicates oxic conditions, whereas the less common green colour indicates occasionally reducing conditions. The absence of fossils, bioturbation, glauconite or other marine indicators suggests a non-marine environment.

The petrophysical logs show that the succession consists of alternating units dominated by sandstone, siltstone or claystone. The core represents one such sandstone interval.

The succession is interpreted as a semiarid fluvial deposit. The convolute bedding was probably caused by liquefaction and water escape due to flood events or seismic shocks heralding the overlying syn-rift succession. 
Zechstein clastics, $1903-1782 m$ b.KB, 1879.5-1758.5 $m$ b.MSL:

This interval is characterized by rapid changes in gamma ray, sonic velocity and resistivity values. Together with the neutron and density readings, the logs indicate a sequence of interbedded sandstone, siltstone and claystone. Cuttings samples indicate a dominance of reddish and redbrown colours, and the presence of minor amounts of white limestone. The upper boundary is located at a pronounced and sharp increase in sonic velocity and resistivity, and a change in neutron and density readings from almost no separation to positive separation.

Skagerrak Formation, 1782-663 m b.KB, 1758.5639.5 m b.MSL:

This interval is characterized by rapid changes in gamma ray and sonic velocity values, which together with the neutron and density readings indicate an interbedded series of sand-, silt-, and claystones. The upper $90 \mathrm{~m}$ are characterized by high gamma ray values with a few lows, which together with the sonic and neutron-density values indicate a claystone and siltstone sequence interbedded with a few sandstone beds and a few carbonate-cemented beds. The sediments are characterized by red and redbrown colours. Anhydrite and minor amounts of limestone occur occasionally. The upper boundary is located at a decrease in gamma ray values and corresponding increase in sonic velocities, and by the transition from red colours below to grey colours above.

Gassum Formation, 663-297 m b.KB, 639.5-273.5 m b.MSL:

This section is characterized by an alteration of welldefined intervals with low and high gamma ray values, indicating interbedded clay- and sandstone beds. The upper boundary is located at a distinct increase in the gamma ray values and corresponding decrease in sonic velocities. The log-readings indicate that the lower part of the section exhibits rapid changes in lithology, the middle part is dominated by claystone, and the upper part characterized by thick sandstone beds. The three intervals can be described as follows:

663-511 m: The log-readings record a thinly interbedded succession of claystone, sandy claystone, sandstone beds, and coal beds. A few carbonate-cemented beds or dolomite beds are recognized. Several upwards fining sequences are seen. Based on the cuttings samples, grey colours dominate. Coal and light brown dolomite are found.
511-370 m: The log-analysis indicates a claystone sequence interbedded with siltstone and a number of distinct coal beds. The claystone in the cuttings samples is dark grey to light grey in colour. Light brown dolomite is also found.

370-297 m: This interval is characterized by blocky gamma ray log-motifs, indicating massive sandstone beds interbedded with claystone. The presence of minor coal beds is suggested by the cuttings samples.

Fjerritslev Formation, 297-126 m b.KB, 273.5-102.5 $m$ b.MSL:

This interval is characterized by consistently high gamma ray values, indicating a uniform sequence of claystone and silty claystone. A marked decrease in the gamma ray values is used to locate the upper boundary which is suggested here to form the boundary between the Quaternary and the Lower Jurassic deposits, thus representing a pronounced hiatus. However, the ostracod fauna found at a depth of $110 \mathrm{~m}$ is indicative of a Pliensbachian age, thus bringing the location of the upper boundary of the formation into doubt. The marked gamma ray decrease mentioned above is situated just below a casing shoe, thus raising the possibility that it may represent an artefact, e.g. the lower limit of the cement connected to the casing. The location of top of the Fjerritslev Formation in this well thus remains a matter of debate; we propose that it is located at $126 \mathrm{~m}$.

The formation in this well cannot be subdivided unambiguously on the basis of log-features. However, log-correlation to the two other well sections suggests the following subdivision (fig. 2):

F-Ia member, 297-219 m, F-Ib member, 219-164 m, F-II member, 164-?138 m, F-III member, ?138-126 m.

Quaternary, $126-53.8 \mathrm{~m}$ b.KB, $102.5-30.3 \mathrm{~m}$ b.MSL (sea floor).

\section{Chronostratigraphy}

Upper Carboniferous, 3031.5-2454 m b.KB, 30082430.5 m b.MSL:

The basal informal lithostratigraphic units in this well, the well-bedded sandstone, siltstone and claystone, and the volcanic rocks and claystone, cannot readily be correlated to known units in other wells or outcrops in 


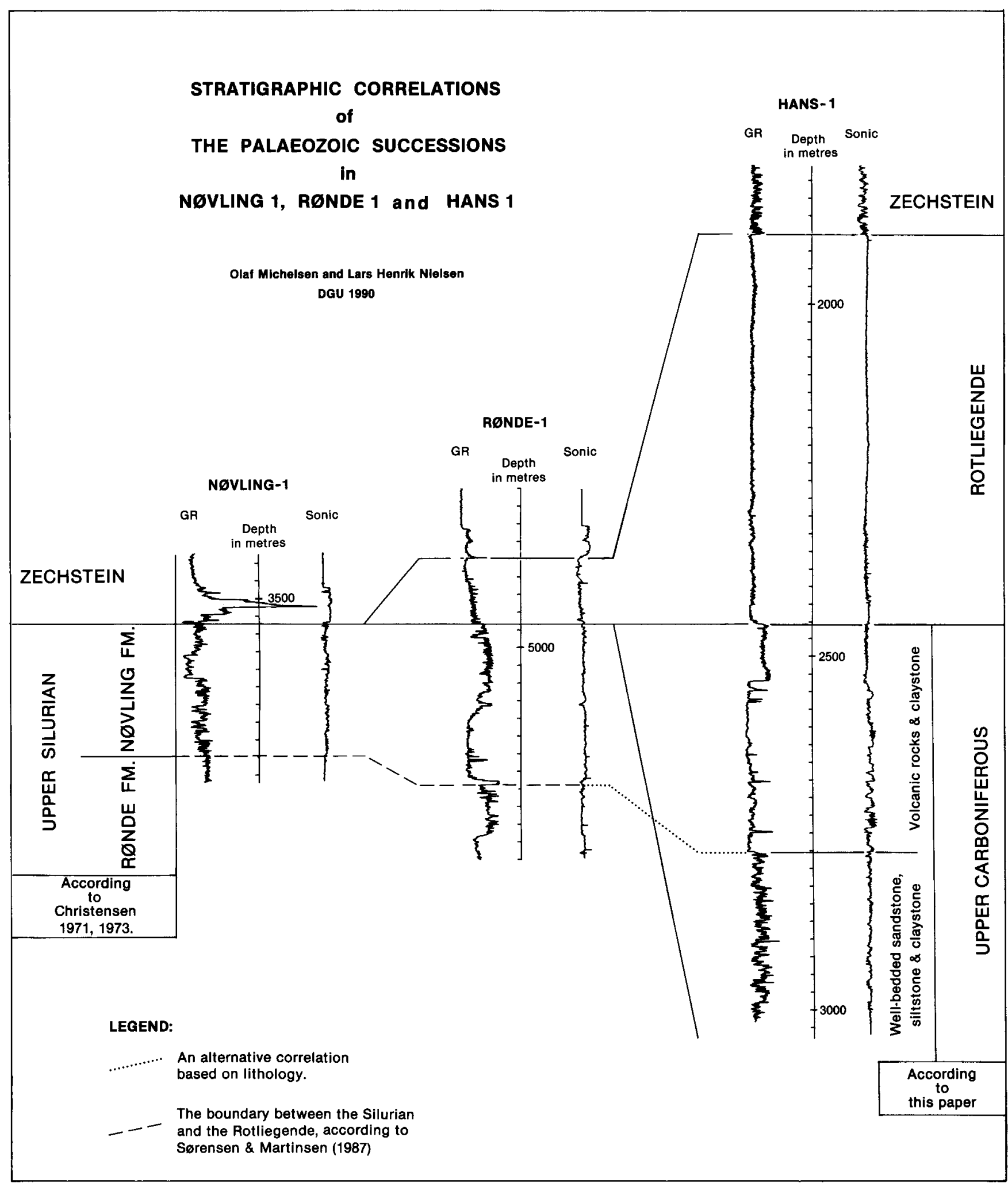

Figure 4: Stratigraphic correlation of the upper Palaeozoic in the Hans-1, Nøvling-1, and Rønde-1 wells. The Silurian age of the Nøvling and Rønde Formations is given in accordance with Christensen (1971 and 1973), and the suggested Late Carboniferous age for the pre-Rotliegende sequence in the Hans-1 well is in accordance with this paper.

If a Rotliegende age is accepted for the Nøvling Formation as suggested by Sørensen \& Martinsen (1987), the "volcanic rocks and claystone" unit in Hans-1 may belong to that formation. The Rønde Formation may then be present below TD of Hans-1, whereas the suggested Carboniferous sequence at the base of Hans-1 is absent further to the west, at least at Rønde and Nøvling locations. 
Scania or Bornholm. Superficially, similar rock sequences are found in the Rønde-1 and Nøvling-1 wells, the Rønde and Nøvling Formations, which are probably of Silurian age (Christensen 1971, 1973), though Sørensen \& Martinsen (1987) discussed the age of the latter formation and referred it to the Rotliegende (fig. 4).

The biostratigraphic data are very sparse. A few palynomorphs found in a sidewall core near the base of the interval have a known range from Late Carboniferous to Permian. Until further material is available, it is here suggested to refer this interval to the Upper Carboniferous as it is overlain by an inferred Rotliegende interval succeeded by Upper Permian clastics. If the revision of Sørensen \& Martinsen (1987) is correct, the interval may be a correlative of the Nøvling Formation, but further data are needed to confirm this.

The (basic to intermediate) volcanic rocks have been dated by the K-Ar method, giving ages of $227( \pm 3) \mathrm{Ma}$ and $216.5( \pm 2) \mathrm{Ma}$, i.e. Triassic ages. These results are regarded as anomalous, since the lithostratigraphic evidences and the available palaeontological and seismic data indicate a Palaeozoic age. The K-Ar ages may be influenced by weathering.

Rotliegende, 2454-1903 m b.KB, 2430.5-1879.5 m b.MSL:

This interval is here referred to the Lower Permian, Rotliegende, mainly on lithostratigraphic grounds.

Zechstein, 1903-1782 m b.KB, 1879.5-1758.5 m b.MSL:

Palynomorphs indicating a Late Permian age were recorded from cuttings samples from 1990-1890 m; no taxa indicating an age older than Late Permian were found in the interval. Neither the log-analyses nor the lithologies observed in the cuttings samples indicate the presence of sedimentary facies known from the Zechstein deposits in the Danish region. The palynomorphs may be regarded as reworked into the Lower Triassic deposits. However, the seismic data from the area show a very distinct, thin seismic interval, bounded by unconformities. The lower unconformity is interpreted to be the very pronounced mid-Permian unconformity, and the upper one is overlain by Triassic rocks (fig. 5). The abrupt changes in log pattern at the boundaries of the interval 1903-1782, as described earlier, may indicate the presence of unconformities (Rider 1986). The tie from the logs to the seismic section, using the well velocity survey, is of sufficient accuracy to justify this correlation between the unconformities seen on the seismic section and those indicated in the well. Based on this correlation and the occurrence of Upper Per- mian palynomorphs in the lower part of the interval it is concluded that the Zechstein is represented by a siliciclastic facies in this area.

The occurrence of Upper Permian palynomorphs in the upper part of the inferred Rotliegende section may be the result of caving.

Triassic, $1782-595 \mathrm{~m}$ b.KB, $1758.5-571.5 \mathrm{~m} \mathrm{b.MSL}$ :

The lowermost part of the Gassum Formation and the Skagerrak Formation is here referred to the Triassic. The biostratigraphic data are sparse, but palynomorph assemblages indicate the presence of Upper Rhaetian deposits. Ostracods found in the upper clay-dominated part of the Skagerrak Formation indicate an early Rhaetian age and brackish-marine conditions, which elsewhere are unknown for the Skagerrak Formation. Further subdivision of the Triassic sequence in this well cannot be established with reasonable certainty. However, scattered rare palynomorphs indicating Rhaetian and Norian ages, were recorded from the upper part of the Skagerrak Formation, whereas the lower part of the formation is probably of Middle and Early Triassic age.

Lower Jurassic, 595-126 m b. KB, 571.5-102.5 m b.MSL:

The Gassum Formation, with the exception of the lowermost part, and the Fjerritslev Formation are here referred to the Lower Jurassic. Determination of the upper boundary is discussed in the lithostratigraphic section. The Lower Jurassic sequence can be subdivided on the basis of biostratigraphic data. Palynomorph assemblages indicate that the top of the Lower Sinemurian occurs approximately $100 \mathrm{~m}$ above the base of Fjerritslev Formation, and the upper part of the Gassum Formation is referred to the Hettangian (fig. 6). However, poor ostracod assemblages suggest that the Lower-Upper Sinemurian boundary occurs within the section referred to the F-Ib member, and the Sinemurian-Pliensbachian boundary occurs near the base of the F-II member.

Middle Jurassic to Tertiary sediments are absent.

Quaternary, $126-53.8 \mathrm{~m}$ b.KB, $102.5-30.3 \mathrm{~m}$ b.MSL (sea floor). 


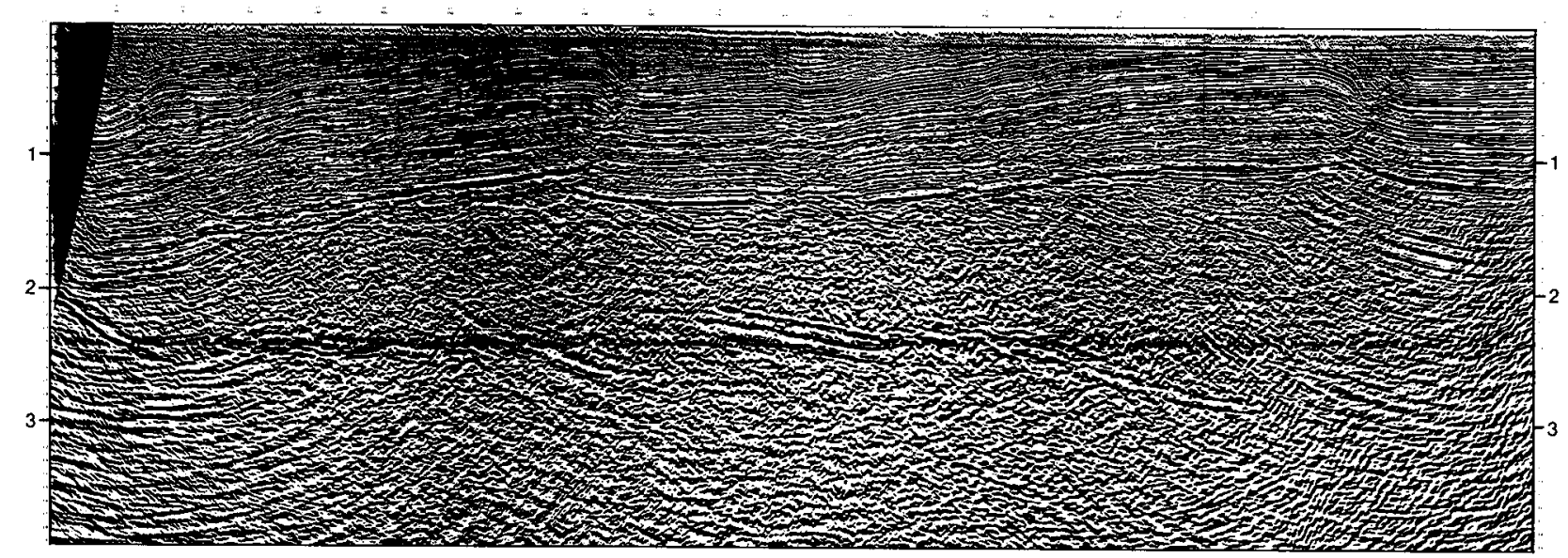

SORGENFREI - TORNQUIST ZONE

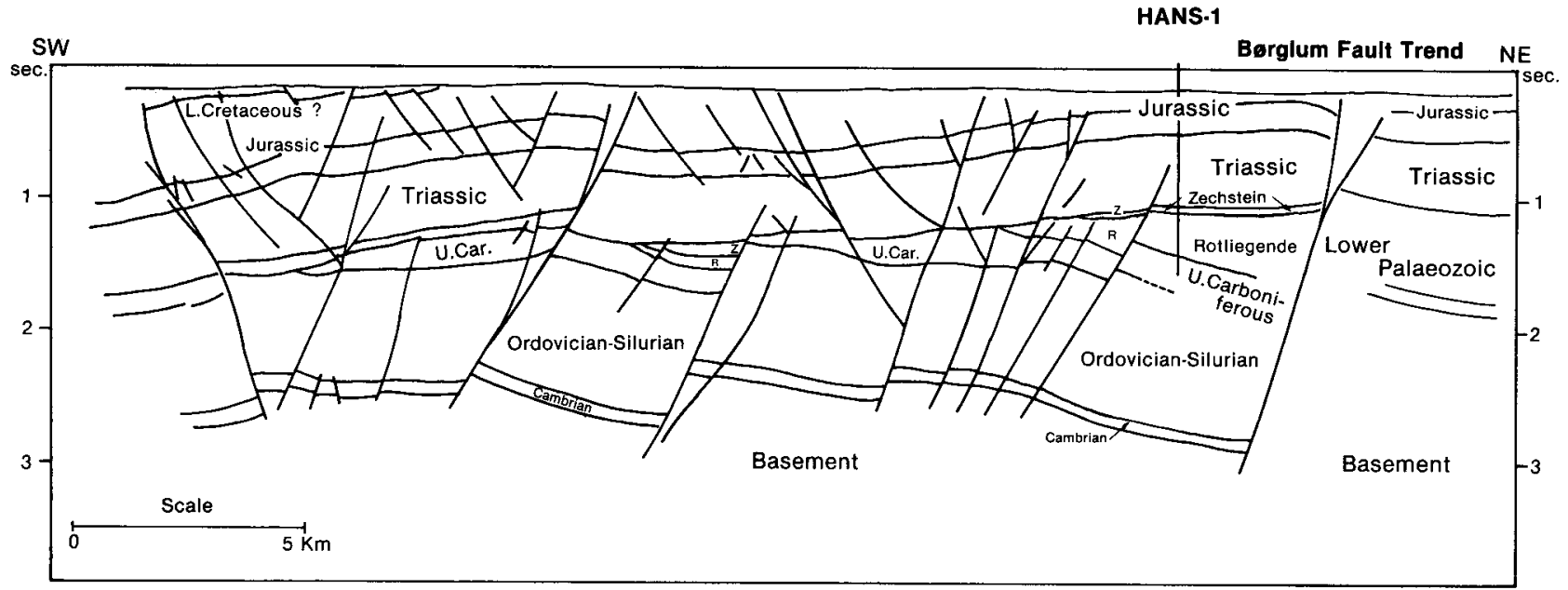

Figure 5: Interpretation of the seismic line K83-005 trough the Hans-1 well. Location of line is shown on fig. 1.

\section{SAEBY-1 (5710/22-1)}

Locality: $57^{\circ} 21^{\prime} 41^{\prime \prime} \mathrm{N}, 10^{\circ} 23^{\prime} 45^{\prime \prime} \mathrm{E}$.

Elevation: Ground $59.9 \mathrm{~m}$ a.MSL, DF $64.3 \mathrm{~m}$ a.MSL.

\section{Lithology and lithostratigraphy}

Rotliegende Group, 1852.8 (TD)-1646.8 m b.DF, 1788.5-1584.5 m b.MSL:

This lithostratigraphic unit is recognized primarily by $\log$ analysis. The section is rather uniformly developed, showing relatively low gamma ray values, high density values, and sonic velocities, a large positive separation of the density-neutron curves, and a very constant caliper value. The upper boundary of the group is defined by these characteristics compared to the overlying Skagerrak Formation. The log-motifs indicate that the interval is dominated by volcanic material. The presence of detrital quartz, clay, and iron hydroxides in cuttings samples and sidewall cores suggest that the interval consists of volcaniclastic deposits and not in situ volcanic rocks.
Skagerrak Formation 1646.8-1111 m b.DF, 1584.51046.7 m b.MSL:

The top of the formation is identified by a very abrupt decrease in gamma ray values and resistivity readings, and a change from positive separation of the neutrondensity curves to almost no separation. The boundary between the Skagerrak and Gassum Formations has been determined in the neighbouring wells, Flyvbjerg-1 and Frederikshavn-1 (Bertelsen 1980), and it is possible to correlate the boundary in Sæby-1 to these two wells, especially to the latter (fig. 6).

A very distinct change in log pattern occurs in all logs at $1325 \mathrm{~m}$ defining a lower and an upper interval (fig. 2). The lower interval, $1646.8-1325 \mathrm{~m}$, is characterized by relatively high and rapidly changing gamma ray values, intermediate and fairly constant sonic velocities, and no or a small positive separation of the neutron-density curves. The top of the interval is marked by a pronounced gamma ray peak and an increase in the sonic velocity, resistivity, and density.

A $16.5 \mathrm{~m}$ core from lower part of the interval (fig. 7) comprises greyish and brownish conglomerates and pebbly sandstones with clasts of quartz, feldspar and 
claystone. Log analysis together with data from the core and cuttings samples indicate that the lower part of this formation is composed of interbedded sandstones, conglomerates, and claystones.

The upper interval $(1325-1111 \mathrm{~m})$ is characterized by low gamma ray values in the lower part, increasing gradually upwards, and high sonic velocities, resistivities, and densities, decreasing upwards. This upper interval of the formation is dominated by sandstone in the lower part being more argillaceous upwards and interbedded by claystones. The uppermost $10 \mathrm{~m}$ consists of greyish claystones.

The two intervals described above define two major depositional trends with smaller changes superimposed. Two similar trends in the Skagerrak Formation in the Frederikshavn-1 well are indicated by the SP log and the resistivity $\log$, and a correlation seems possible.

Gassum Formation, 1111-1077 m b.DF, 1046.71012.7 m b.MSL:

The upper boundary of the formation is placed at the uppermost pronounced gamma ray low, overlain by an interval with high values tentatively referred to the F-Ia member of the Fjerritslev Formation (see below).

The lower $11 \mathrm{~m}$ and uppermost $3 \mathrm{~m}$ of the Gassum Formation are characterized by low gamma ray values indicating a dominance of sandstone. The middle part shows intermediate and high gamma ray values indicating interbedding of claystone and argillaceous sandstone which is confirmed by the cuttings samples. The Gassum Formation in this well is comparable to the upper part of the formation in the Børglum-1 well, whereas the Gassum Formation in the Flyvbjerg-1 and Frederikshavn-1 wells is dominated by sandstone (fig. $6)$.

Fjerritslev Formation?, 1077-1023 m b.DF, 1012.7958.7 m b.MSL:

?F-Ia member, 1077-1023 m: The upper boundary of this section is placed at $1023 \mathrm{~m}$ where the gamma log changes character from highly variable below to more uniform above. The sonic velocities in this section are generally lower than in the underlying and overlying sections, whereas the neutron-density curves indicate continuity in deposition from the underlying Gassum Formation. The section is interpreted as claystone interbedded with silty and sandy claystones and thin sandstone beds; to some extent, therefore, this interval resembles the F-Ia member. The lithostratigraphic status of this section is questionable, however, as the log-motifs are not typical of the Gassum Formation, yet nor are they closely comparable to those of the F-Ia member of the Fjerritslev Formation. Furthermore, the presence of the F-Ia member has not yet been proved in neighbouring wells located in North Jylland. The section is here tentatively referred to the F-Ia member due to the log-features and lithology described above, although clearly more sand-rich than elsewhere. The section may correlate lithostratigraphically with the lowermost part of the Fjerritslev Formation interbedded with the Gassum Formation in the Vedsted-1 well (see Michelsen 1978, fig. 12).

Fjerritslev Formation, 1023-821 m b.DF, 958.7-756.7 m b. MSL:

F-Ib member, 1023-975.5 m: This section is characterized by uniform log-motifs, high gamma ray values and positive separation of the neutron-density curves. It is, therefore, interpreted as a uniform claystone sequence. The upper boundary is placed at a decrease in the gamma ray values and a pronounced increase in sonic velocities.

F-II member, 975.5-912 m: The upper boundary is located at an abrupt increase in the gamma ray values and decrease in sonic velocities; this boundary is readily recognized in wells in the basin as well as in the borderzone. The gamma ray values decrease upwards through the member whereas sonic readings are constant. The neutron-density logs show an upward decrease in positive separation. The gamma ray log and the neutron-density logs indicate a claystone sequence becoming silty and sandy upwards, and the uppermost twenty metres are dominated by siltstone. Log analyses indicate that the uppermost couple of metres of this siltstone is carbonate cemented. The member is readily correlated with the F-II member in the Frederikshavn-2 well (fig. 6).

F-III member, $912-859 \mathrm{~m}$ : The section is characterized by uniform and high gamma ray values and low sonic velocities. A combined log analysis suggests a uniform claystone sequence. The upper boundary is located at an increase in sonic velocities, which can be correlated throughout the basin. The gamma ray values increase above the boundary in this well, a feature which is only seen in the Frederikshavn-1 well.

The log-motifs of the F-III member in this well correlate closely with those of the Frederikshavn-2 well (fig. 6). The decrease in gamma ray values in a thin basal interval is a characteristic feature, which is also recorded by a deflection of the SP-log in neighbouring wells, although higher in the member. It is a log-feature recognizable in most wells in the Danish Subbasin, and has been shown to coincide with the top of the Upper Pliensbachian (Michelsen 1989); see below.

F-IV member, $859-821 \mathrm{~m}$ : This interval is characterized by upwards-decreasing gamma ray values and con- 
Figure 7:

Well: Sæby-1

Core 2: $1612.2-1630.00 \mathrm{~m}$ b.DF

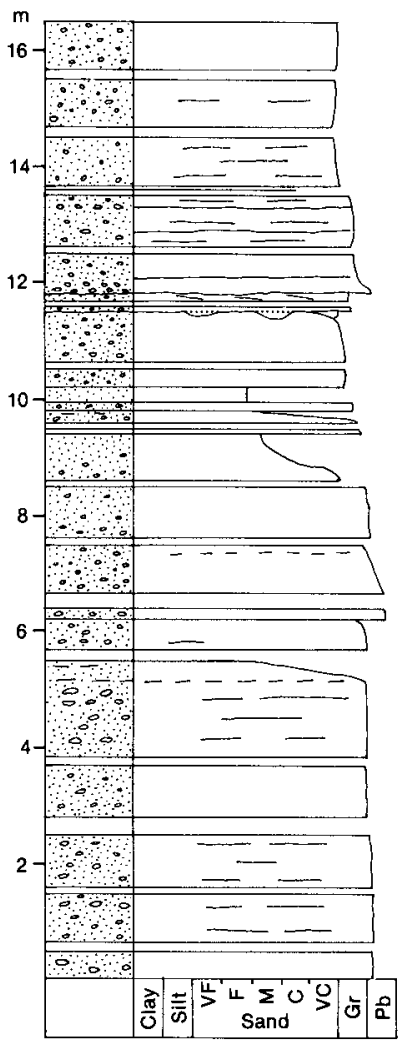

Description: Sandstone, very pebbly, grading to clastsupported conglomerate, loose to firm, grey, brownish grey, greenish grey, greyish red. Very poorly sorted with grain size ranging from very coarse to fine. Pebbles constitue from $10 \%$ to $70 \%$ of rock volume. The pebbles are up to $5 \mathrm{~cm}$ across, angular to subangular, rarely rounded. They consist of quartz, feldspar, weathered crystalline basement rock, and few scattered claystone clasts.

Bedding is poorly defined; faint parallel stratification occurs locally. The conglomerate seems disorganized. The sandstone is locally moderately sorted, and pockets or layers of clast-supported conglomerate with an open framework are also present locally.

Interpretation: The poorly defined stratification, the very poor sorting, the angularity of the pebbles, and the immature mineralogy indicate a short distance of transport without significant sorting. The absence of fossils, bioturbation, glauconite, or other marine indicators suggest a non-marine environment.

The succession is interpreted as wadi sediments or stream-flood dominated alluvial fan deposits.

The interpretation of the seismic line (fig. 10) indicates the presence of basement rock on the neighbouring footwall and Triassic onlap onto the basement. It is likely that the rock fragments were derived from this block before rising base-level resulted in northeastward onlap.

stant intermediate sonic velocities. The upper boundary is located at a shift to low gamma ray values indicating a sandstone sequence, referred here to the Haldager Sand Formation. The neutron-density readings indicate a claystone succession, becoming more sandy upwards and interbedded with thin sandstone beds. This coarsening upwards trend is not a common feature of the member, which is normally clay-dominated in the upper part. In this well, only the uppermost 2-3 $\mathrm{m}$ constitute claystone. The lowermost 17 metres of the member show very high gamma ray values compared to the underlying F-III member.

Fig. 6 occurs as a fold-out after p. 37
Haldager Sand Formation, 821-801 m b.DF, 756.7736.7 m b.MSL:

The section is characterized by relatively low but variable gamma ray values and variable sonic velocities indicating interbedded sandstone and claystone. The upper boundary is located at the top of a massive sandstone bed overlain by a more clay-dominated sequence as reflected by the gamma ray log (fig. 6). The sonic velocities are relatively high and constant across this boundary. The log-motifs of the formation in this well correlate with those of the neighbouring Frederikshavn-1, Flyvbjerg-1, and Børglum-1 wells (see Michelsen 1978, fig. 15). 
Flyvbjerg Formation, 801-737 m b.DF, 736.7-672.7 m b.MSL:

The upper boundary of the formation is placed at the top of a sand-dominated interval, which is overlain by claystones referred to the Børglum Formation. This is based on correlation to the Haldager-1, Flyvbjerg-1, and Børglum-1 wells (cf. Michelsen 1978, fig. 15). The formation can be subdivided into two units in this well, as in the three wells mentioned above.

The lower unit, $801-773 \mathrm{~m}$, is dominated by claystone interbedded with sand- and siltstones, as indicated by the serrate pattern of the gamma ray, neutron, and density logs.

The upper unit, $773-737 \mathrm{~m}$, is characterized by low gamma ray values with minor peaks, suggesting a massive sandstone unit with thin argillaceous intercalations. Log analysis indicates that the lower and upper two metres of the unit are carbonate-cemented, as known from other wells in the Fennoscandian Border Zone.

The pronounced difference between the two units of the Flyvbjerg Formation in this well may form the basis for establishing two new members of the formation. The lithostratigraphical validity of these units is supported by the occurrence corresponding features in the Børglum-1, Flyvbjerg-1, and Haldager-1 wells, but may be restricted to the Fennoscandian Border Zone.

Børglum Formation, 737-711 m b.DF, 672.7-646.7 m b.MSL:

The section is characterized by uniform high gamma ray values and low but variable densities, indicating a uniform claystone sequence. The log-motifs correlate closely with those of other Danish wells, and the thickness of the formation corresponds to that known from the wells in the border zone. The upper boundary is located at a marked decrease in the gamma ray values. This log break occurs a few metres above an increase in the sonic velocities, but the gamma ray readings are here used to define the boundary.

Frederikshavn Formation, 711-606 m b.DF, 646.7541.7 m b.MSL:

The section is characterized by a general decrease in gamma ray values upwards and by constant sonic velocities (fig. 8). The upper boundary is located at a marked increase in gamma ray values, indicating the change from sandstones of this formation to clay-dominated sediments of the overlying Vedsted Formation. The formation can be subdivided into the three units, A, B, and C, described in Michelsen (1978).
Unit A, 711-?683 m, consists of sandy claystones containing an increasing sand content upwards. The upper boundary is located at a sonic log break, but correlation by means of the gamma ray log to the nearby Frederikshavn-1 well may move this boundary approximately ten metres upwards.

Unit B, ?683-641 m, is an upwards-coarsening sequence dominated by silt- and sandstones, interbedded with thin argillaceous beds. The upper boundary is located at the top of a massive sandstone bed overlain by a clay-dominated sequence. The pattern of the gamma ray readings is readily correlated to most well sections in the basin.

Unit C, 641-606 m, generally coarsens upwards. The lower part is characterized by relatively high but variable gamma ray values, and the upper part by low gamma ray values. The sonic velocities are rather high and constant. In combination with the neutron-density logs, these log-features reflect an upper sequence of pure sandstone twenty metres thick, which is not recognized more centrally in the basin. The underlying part of the unit consists of interbedded claystone and siltstone.

Vedsted Formation, 606-440 m b.DF, 541.7-375.7 m b.MSL:

The entire section is here referred to the Vedsted Formation although the upper part, characterized by glauconite, may belong to a new lithostratigraphic unit. Thus, the upper boundary is located at the base of the overlying Chalk Group. The formation in this well is subdivided in four units, which may be correlated to other wells, e.g. to Børglum-1 and Hyllebjerg-1 (fig. 9).

Unit-1, 606-588 m, is a clay-dominated sequence with increasing gamma ray values upwards. In the Hyllebjerg-1 well, centrally in the basin, this unit forms the transition between the sandy Frederikshavn Formation and the clay-rich Vedsted Formation, indicating continuous sedimentation in this area. In the Sæby-1 well as elsewhere in the border zone, the change in sedimentation was more abrupt. The upper boundary of unit-1 is located at a decrease in gamma ray values.

Unit-2, 588-550 $\mathrm{m}$, is characterized by increasing gamma ray values upwards, indicating silty claystone in the basal part and claystone in the upper part. There is an abrupt change in gamma ray values between these two intervals. The upper boundary of unit- 2 is located at the base of a gamma ray low.

Unit-3, $550-485 \mathrm{~m}$, is characterized by high gamma ray values, which fluctuate significantly in the lower part, 


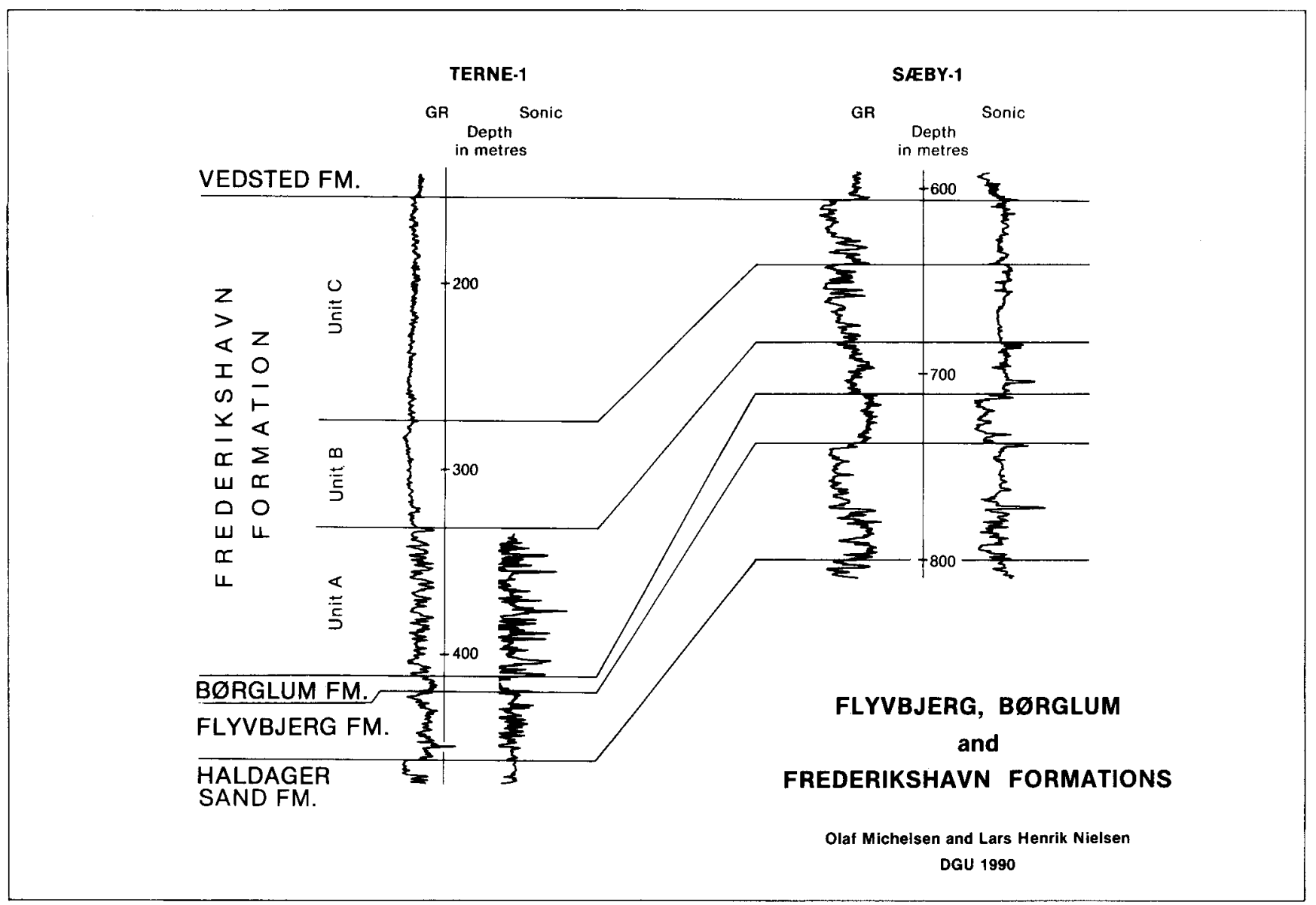

Figure 8: Correlation of the Flyvbjerg, Børglum and Frederikshavn Formations, and subdivision of the latter in the Sæby-1 and Terne-1 well.

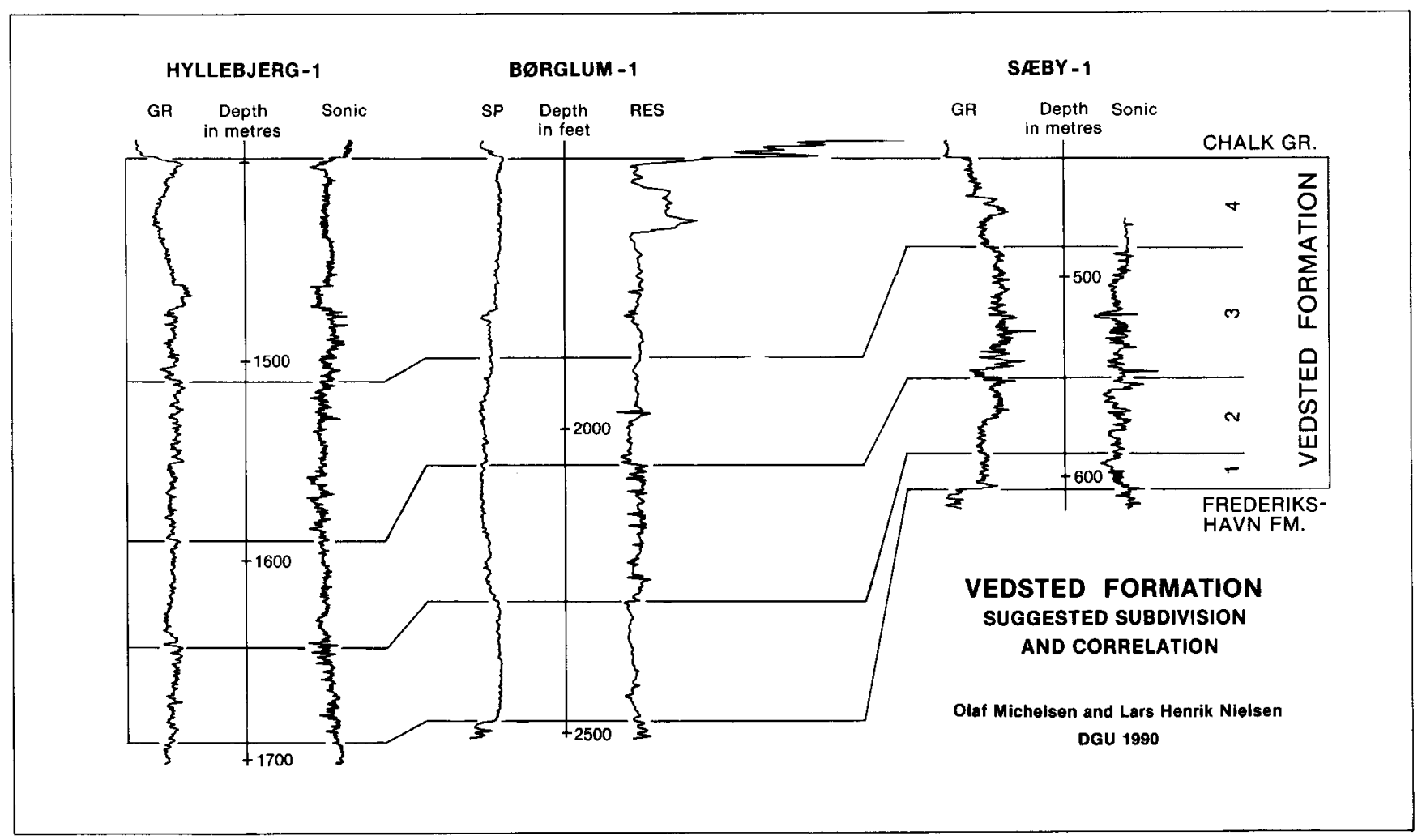

Figure 9: Correlation of the Vedsted Formation in Sæby-1 with the Børglum-1 and Hyllebjerg-1 wells. 
indicating interbedded claystone and siltstone succeeded by more uniform claystones. The upper boundary is located at sudden drop in gamma ray values.

Unit-4, 485-440 $\mathrm{m}$. The upper boundary is located at the base of the Chalk Group. The section is characterized by lower gamma ray values and higher sonic velocities than unit-3, indicating a siltstone sequence interbedded by a few metres thick claystone beds. Analysis of the cuttings samples indicate a significant amount of glauconite in the upper $10 \mathrm{~m}$ of the interval. A corresponding glauconite rich interval is reported from this lithostratigraphic level in the Frederikshavn-1 well (Larsen 1966). Preliminary log-correlation with the Hyllebjerg-1 well shows this glauconite rich interval in a lithostratigraphic position corresponding to the Rødby Formation.

Chalk Group, 440-221 m b.DF, 375.7-156.7 m b.MSL:

The gamma ray log is the only log available through this interval; it was measured through the casing, resulting in reduced values. The values are very low and on a constant level, indicating a uniform limestone sequence. The upper boundary is clearly marked by an increase in gamma ray values.

Quaternary, 221-4.4 m b.DF, $156.7 m$ b.MSL - 59.9 $m$ a.MSL (ground).

\section{Chronostratigraphy}

Rotliegende, 1852.8 (TD) -1646.8 m b.DF, $1788.5-$ $1584.5 \mathrm{~m} \mathrm{b.MSL}$ :

This volcaniclastic sequence is referred to the Rotliegende on the basis of regional lithostratigraphic considerations.

Triassic, $1646.8-1111 \mathrm{~m}$ b.DF, $1584.5-1046.7 \mathrm{~m}$ b.MSL:

The Skagerrak Formation is referred to the Triassic on lithostratigraphic grounds in accordance with previous studies (Bertelsen 1980).

Lower Jurassic, 1111-821 m b.DF, 1046.7-756.7 m b.MSL:

The top of the Hettangian is indicated by miospores recorded from the F-Ia member at a depth of $1065 \mathrm{~m}$, and the top of the Lower Sinemurian occurs three metres above the F-Ia/F-Ib member boundary. This latter stratigraphic determination is in accordance with that known from the basin (Michelsen 1989).

The presence of the Upper Sinemurian is not indicated by biostratigraphic data.

The top of the Pliensbachian is determined on the basis of the ostracod fauna at a depth of $910 \mathrm{~m}$, which is two metres above the boundary between the F-II and F-III members. These bio- and lithostratigraphic data correlate closely to those known from the Frederikshavn-1 and -2 wells (see also fig. 6). In the Frederikshavn-2 well, biostratigraphic dating of a continuously cored sequence across the member boundary indicates a hiatus corresponding to the lower part of the Upper Pliensbachian (Michelsen 1975 and 1989) which may explain the small thickness of the Pliensbachian part of the F-III member in these wells.

The overlying part of the Fjerritslev Formation, 910$821 \mathrm{~m}$, is here referred to the Toarcian. Palynomorphs indicating a Toarcian age are recorded up to a depth of $824 \mathrm{~m}$.

Middle Jurassic, 821-801 m b.DF, 756.7-736.7 $\mathrm{m}$ b.MSL:

The Haldager Sand Formation is here referred to the Middle Jurassic on lithostratigraphic grounds in accordance with previous studies (Michelsen 1978 and 1989). Miospores indicating a Middle Jurassic age were found at a depth of $779 \mathrm{~m}$, in the basal part of the Flyvbjerg Formation. Data from the basin indicate a regional hiatus between the two formations (Michelsen 1989). The presence of these miospores may, therefore, be the result of reworking, or they suggest that the two formations are not separated by a hiatus in this area.

Upper Jurassic, 801-641 m b.DF, 736.7-576.7 m b.MSL:

The Flyvbjerg Formation, Børglum Formation, and units $\mathrm{A}$ and $\mathrm{B}$ of the Frederikshavn Formation are referred to the Upper Jurassic on the basis of marine and terrestrial palynomorphs.

The top of the Kimmeridgian occurs in the basal part of the Børglum Formation, at a depth of $734 \mathrm{~m}$. Precise determination of the Oxfordian has not yet been possible, but the Upper Oxfordian is assumed to be present within the Flyvbjerg Formation.

The top of the Volgian occurs uppermost in unit B of the Frederikshavn Formation, at $645 \mathrm{~m}$. This correlates with the study of the Haldager-1 well (Davey 1982). The Jurassic-Cretaceous boundary is, therefore, located at the mentioned lithostratigraphic boundary. 


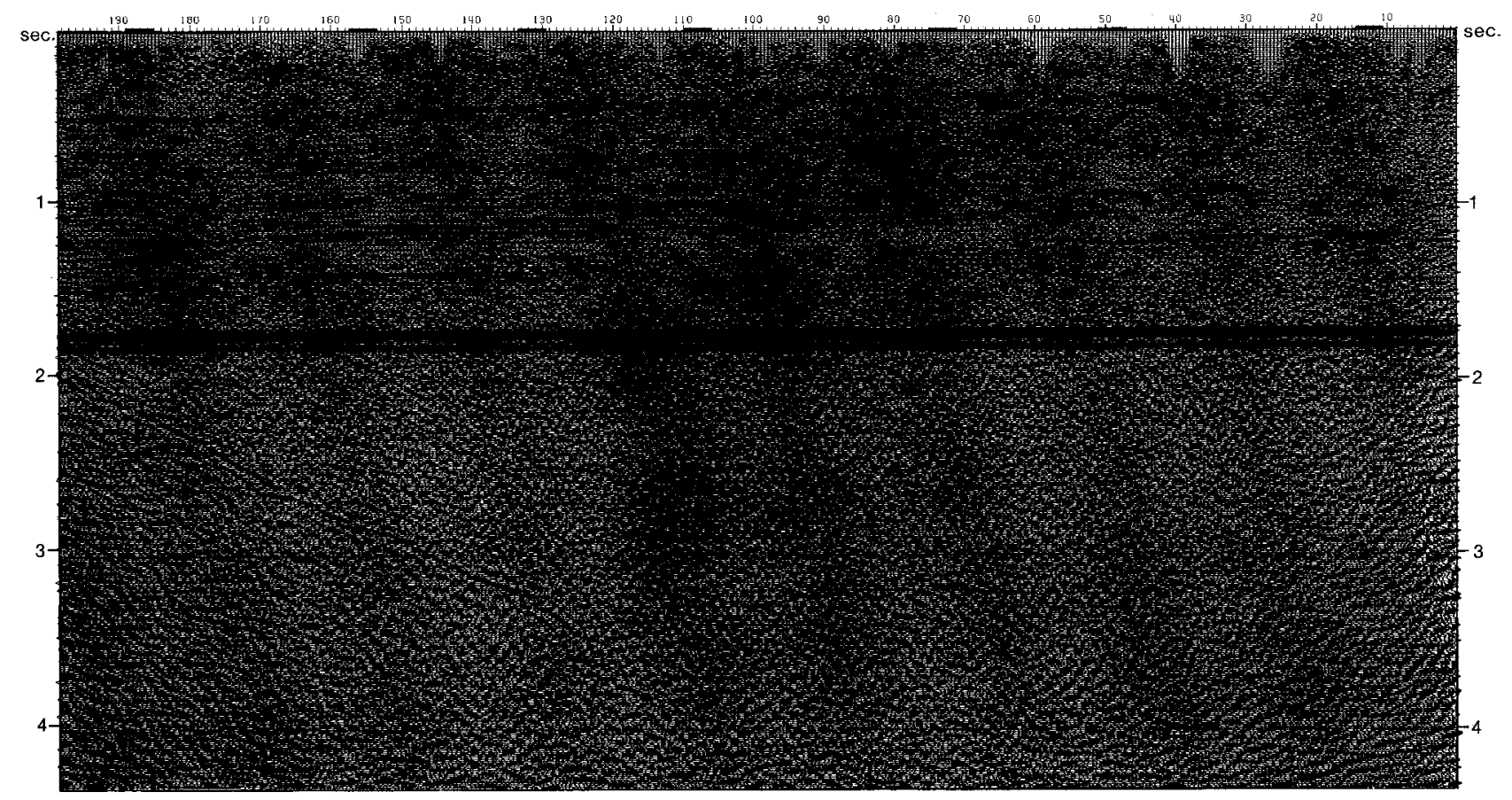

SKAGERRAK KATTEGAT PLATFORM

SEEBY-1

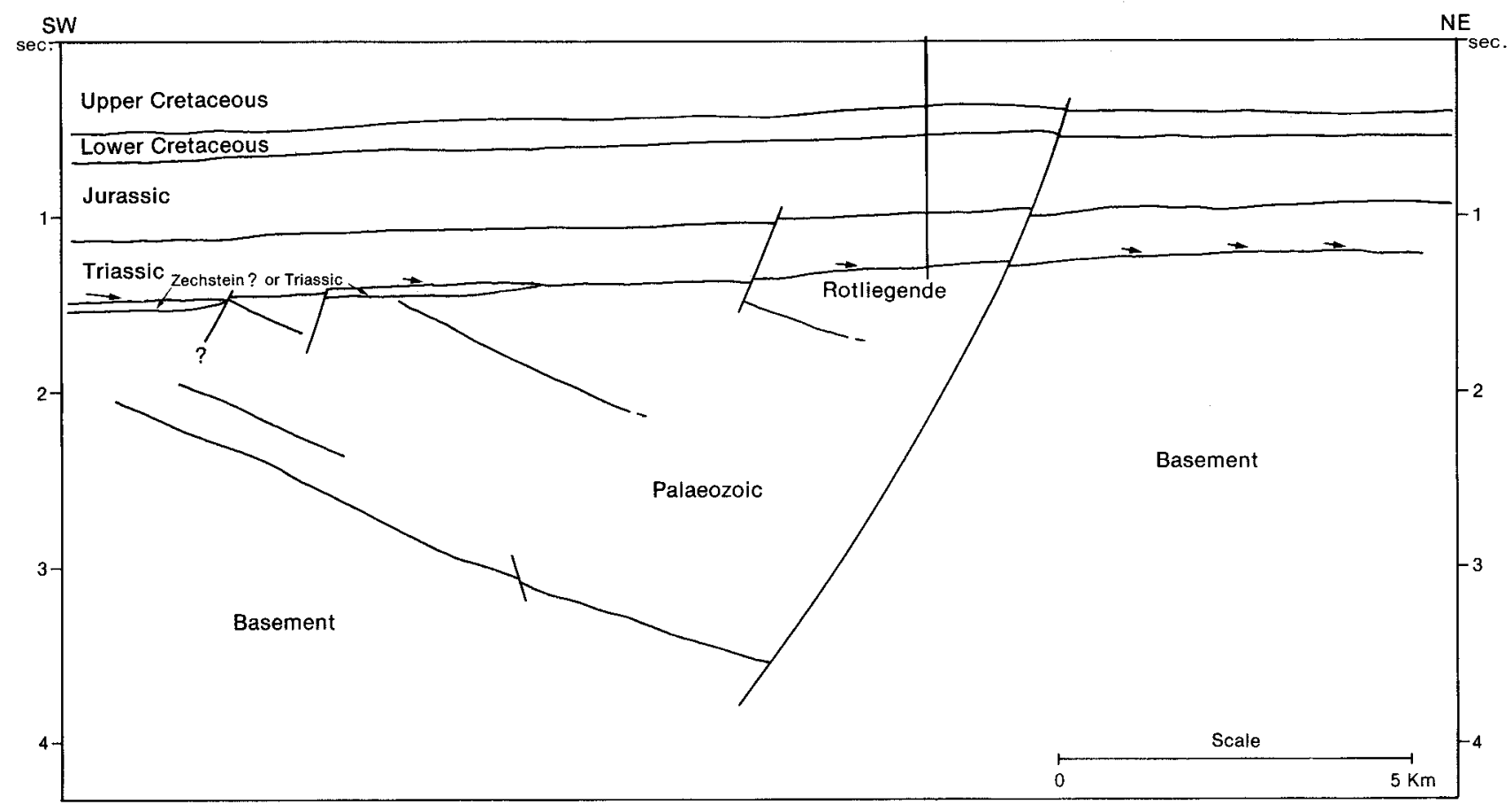

Figure 10: Interpretation of seismic line DN 86D-003 through the Sæby-1 well. The location is shown on fig. 1.

Lower Cretaceous, 641-440 m b.DF, 576.7-375.7 m b.MSL:

Unit $\mathrm{C}$ of the Frederikshavn Formation and the Vedsted Formation are here referred to the Lower Cretaceous, although the upper boundary is defined on lithostratigraphic data only.

Terrestrial palynomorphs indicate a Late Ryazanian to Early Valanginian age for unit $\mathrm{C}$ of the Frederikshavn Formation.
The top of the Hauterivian is located within unit-2 of the Vedsted Formation, at $570 \mathrm{~m}$. Rich palynomorph assemblages have been recorded.

The succeeding upper unit- 4 of the Vedsted Formation, are referred to the Aptian and the Albian. Palynomorph assemblages indicate the top of the Aptian at $465 \mathrm{~m}$, whereas definitive Albian indicators were not observed above this level. Nannofossils and foraminifera found below this depth, however, indicate the presence of sediments of Albian age. 
In the neighbouring wells, Børglum-1, Frederikshavn-1, and Haldager-1, previous biostratigraphic studies (Sorgenfrei \& Buch 1964) suggest that the sequence that correlates lithostratigraphically with the upper unit- 4 is of to Cenomanian to Turonian age. Thus, there are clearly difficulties in establishing a valid stratigraphic correlation of the Cretaceous sequences in this part of the border zone. Further bio- and lithostratigraphic studies are needed to evaluate the chronostratigraphy.

Upper Cretaceous, 440-221 m b.DF, 375.7-156.7 m b.MSL:

The Chalk Group is referred to the Upper Cretaceous. On the basis of the foraminifera and nannofossil assemblages, the entire sequence in the Sæby-1 well is referred to the Santonian and Campanian. This preliminary biostratigraphic analysis thus indicates the presence of a hiatus corresponding to the Cenomanian, Turonian, and Coniacian between the Chalk Group and the underlying Vedsted Formation. The correlation mentioned previously with older wells within the border zone suggests that the Cenomanian and Turonian are represented by clastic facies, and probably comprise upper unit-4 of the Vedsted Formation as defined in the Sæby-1 well. Further stratigraphic investigations are necessary to confirm this suggestion.

Tertiary was not recorded in the well.

Quaternary, 221-4.4 m b.DF, 156.7 - 59.9 m.a.MSL.

\section{TERNE-1 (5611/23-1)}

Locality: $56^{\circ} 20^{\prime} 39^{\prime \prime} \mathrm{N}, 11^{\circ} 30^{\prime} 20^{\prime \prime} \mathrm{E}$.

Elevation: Ground (sea floor) $19.1 \mathrm{~m}$ b.MSL, RT 37.3 $\mathrm{m}$ a.MSL.

\section{Lithology and lithostratigraphy}

Quartzite, 3363 (TD)-3352 m b.RT, 3325.7-3314.7 m b.MSL:

This lowermost part of the drilled section is characterized by lower gamma ray values than in the overlying sequence, and by a negative separation of the neutrondensity curves. The neutron log indicates very low porosities and the density log reflects high densities. These log-characters indicate the presence of a well- cemented coarse clastic sedimentary rock. The cuttings samples show the occurrence of quartzite. A core from the interval 3358-3356 m consists of greyish, occasionally reddish, indurated quartzite (fig. 11).

High gamma ray unit, $3352-3173.5 \mathrm{~m}$ b.RT, 3314.7$3136.2 \mathrm{~m}$ b.MSL:

This section, which is informally named the "high gamma ray unit", is characterized by very high gamma ray values, including intervals of extremely high values exceeding 600 API units. The neutron-density curves show a pronounced positive separation. The upper boundary is placed where the gamma ray values decrease to more normal, but still high, clay values. Integrated analysis of the gamma ray, sonic, neutron, and density logs indicate the presence of a claystone sequence, probably rich in organic material. A large number of sidewall cores comprise dark grey to black, occasionally very carbonaceous, and non-calcareous claystones. The lowermost part of the section, 3352$3340 \mathrm{~m}$, shows reduced positive separation of the neutron-density curves, and one sidewall core comprises grey siltstone. In the interval $3340-3285 \mathrm{~m}$, which is characterized by a relative lowering of the gamma ray values, light to dark grey colours occur. Peaks found above this level on the sonic and neutron-density curves coincide with lows on the gamma ray curve record the presence of limestone beds, $1-2 \mathrm{~m}$ thick.

Dark grey - black claystone, 3173.5-2938 m b.RT, 3136.2-2900.7 m b.MSL:

This section is characterized by high gamma ray values and a relatively uniform positive separation of the neutron-density curves. The sonic curve shows high and fairly constant values. The upper boundary is located at a decrease in gamma ray readings to normal clay values and a slight increase in sonic velocities. Sidewall cores and cuttings samples show the presence of a dark grey to black and non-calcareous claystone with minor interbeds of light grey siltstone. Two intervals, 2-7 metres thick, in the middle of the section show very high gamma ray values and may indicate intervals enriched in organic material. It should be noted, that the caliper $\log$ records significant intervals of caved hole, making log interpretation somewhat risky.

Interbedded claystone and siltstone, 2938-2744.5 m b.RT, 2900.7-2707.2 m b.MSL:

The section is characterized by rather high gamma ray readings and positive separation of the neutron-density curves, indicating a clay-dominated sequence. The 


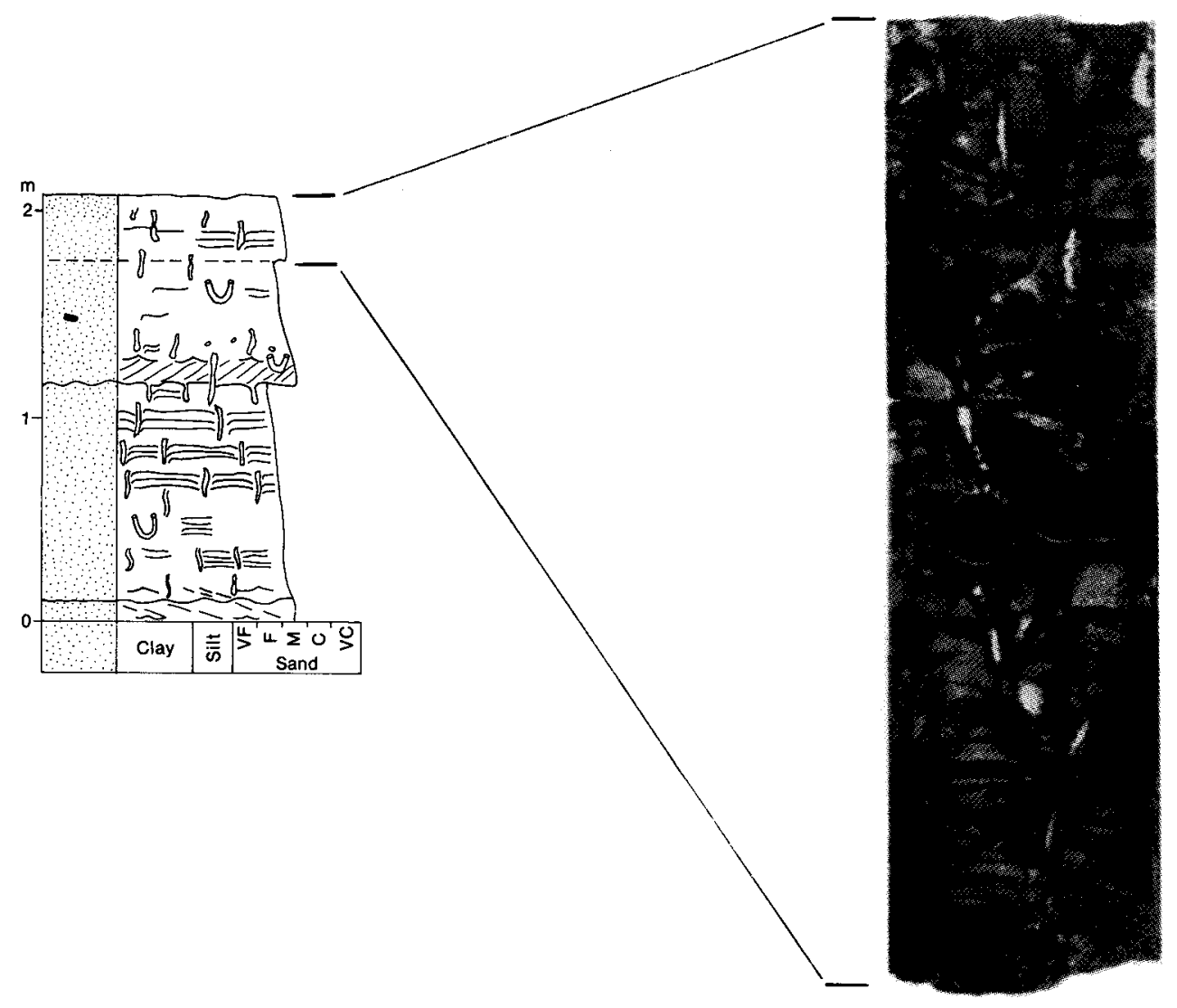

Figure 11:

Well: Terne-1

Core 1: 3356-3358 m b.RT

Description: Quartzite, fine to medium grained, well to moderately sorted, light to dark grey, slightly reddish in places, well cemented, extensive quartz overgrowths, very hard, no visible porosity. Thin sections show that quartz grains and quartz cement constitute $80-90 \%$, feldspar less than $5 \%$, and pore filling clay $5-10 \%$ of the total rock volume. (P.R. Andersen pers. com). Grains are well rounded when unaffected by pressure solution.

Depositional structures are masked by bioturbation together with intensive compaction and diagnesis. Two fining-upward sequences are present beginning with large scale cross-bedding overlain by finely laminated sandstone. In the lower sequence, the cross-stratification is very faint probably due to bioturbation. In the upper sequence the upper part of the cross-bedded layer is bioturbated and the upper set boundary obliterated. The lamination that succeeds the two cross-sets consists of white to light grey laminae and lenses up to $2 \mathrm{~cm}$ thick alternating with dark grey laminae approximately $1 \mathrm{~mm}$ or less thick. The lamination is disturbed by abundant vertical burrows up to $25 \mathrm{~cm}$ long with a diameter of approximately $0.5 \mathrm{~cm}$. The burrows are filled with white or transparent quartz grains and appear quartz-cemented. Some have a clay lining. The most common burrow is of Skolithos-type. Some burrows seem to be paired on bedding surfaces and may be of Arenicolites-type. Possibly U-shaped burrows with protusive spreite (Diplocraterion?), and horizontal burrows with a diameter of $0.2-1 \mathrm{~cm}$, (Planolites?), are also present. Some intervals appear to be almost completely bioturbated.

Interpretation: The trace fossil assemblage suggests a shallow marine environment, and the grain size, sorting, grain shape and the maturity of the rock suggest moderate energy level and repeated reworking. The cross-beds indicate bedform migration by strong currents followed by periods of calmer conditions when the succeeding laminated sandstone was deposited. The lamination records regular changes in current regime; it is very similar to structures described from outcrops of the Hardeberga Sandstone in Scania interpreted as tidal lamination (Hamberg 1991). The limited core data do not allow a precise interpretation of the position within the shallow marine environment. However, based on the very close similarity to the outcrops, the cores may be compared to the A-unit of Hamberg, interpreted to represent abandoned backbarrier tidal channel fill. 
sonic velocities decrease slightly upwards through the lower half of the interval, and are fairly constant in the upper part. The sonic curve has a characteristic nervous character compared to the intervals above and below. The upper boundary is located at a pronounced drop in gamma ray values and a corresponding increase in sonic velocities; these log-breaks are interpreted to record the base of a series of volcanic rock. With the exception of the lowermost 40 metres, the caliper log records a significantly enlarged hole, making lithologic $\log$ interpretation difficult. Cuttings samples and a few sidewall cores taken within the interval comprise grey and dark grey claystones with a variable carbonate content. The neutron-density curves display intervals of negative separations alternating with intervals of positive or no separation, and the gamma ray values and the sonic velocities show large variations. These $\log$ features and the cuttings sample lithology suggest that the lowermost interval is a siltstone interbedded with claystone. The cuttings samples from the uppermost part of the interval beneath the volcanic rock series show signs of thermal alteration.

Dark grey, brownish claystone, 2744.5-2301 m b.RT, 2707.2-2263.7 m b.MSL:

This section is characterized by uniform gamma ray values, typical of claystones. The neutron-density curves show a positive separation and the sonic curve a high, constant level with peaks of low values. At the base and in the lower part of the section and in the upper part, intervals with low gamma ray readings and very high sonic velocities occur. The upper boundary is located at a decrease in gamma ray and resistivity readings.

Analysis of the gamma ray, neutron, and density logs suggests a very uniform sequence of claystones, which from the sidewall cores and cuttings samples can be described as grey or dark grey, brownish, and calcareous. Calcite veins and minor amounts of siltstone are described from the cuttings samples. Grey to green claystones were recognized near the base of the interval. The $\log$ features of the uppermost interval, 2315-2301 m, indicate claystone to be dominant; cuttings samples show grey, reddish brown, and greyish green colours.

Cuttings samples, sidewall cores, and the log-readings indicate that the discrete intervals mentioned above with low gamma ray values comprise volcanic rocks. The basal interval is $30 \mathrm{~m}$ thick, and the upper interval is $82 \mathrm{~m}$ thick. Volcanic layers, 1-4 m thick, occur in the lower part of the section. The indurated and metamorphosed character of the sediments overlying the volcanic rocks, and the lack of log evidence for weathered upper contacts indicate that the volcanic rocks are intrusive in nature.

This claystone dominated sequence is distinguished from that below by having a lighter grey colour and by its petrophysical features. The claystone sequence is situated between two levels with volcanic rocks. Due to lithological character (e.g. the colours) it cannot be referred to the Rønde Formation, which is the only claystone formation with associated volcanics known in the basin. This informal lithostratigraphic unit may instead be tentatively recorded as equivalent to the $\mathrm{Co}-$ lonus Shale.

Zechstein clastics, 2301-2263.5 m b.RT, 2263.7$2226.2 \mathrm{~m}$ b.MSL:

This interval is characterized by an upward decrease in gamma-ray, sonic, and resistivity readings and an upward decreasing positive separation of the neutron and density curves. The upper boundary is defined by an increase in gamma ray and caliper, and subtle decreases in sonic velocity and resistivity in the interval above. The log patterns suggest claystones and clayey sandstones in the lower part, with a general decrease in clay upwards. In the upper part the claystone content increases again. Cuttings samples indicate that the claystones are dark red, sandy and dolomitic, and the sandstones are white, dolomitic and contain glauconite. Four sidewall cores represent grey and brown sandstones.

Skagerrak Formation, 2263.5-1292 m b.RT, 2226.2-1254.7 m b.MSL:

The Skagerrak Formation in this well is characterized by rapid changes in gamma ray and sonic velocity values, which together with the neutron and density readings indicate an interbedded series of sandstone, siltstone, and claystones. The upper boundary is located at a decrease in gamma ray values, indicating the base of a sandstone sequence, which is also represented on the caliper log. The boundary is further indicated by a change from redbrown colours below to grey and dark grey colours above. The lithology is characterized by red and redbrown sand-, silt, and claystones. Anhydrite occurs occasionally.

Through large intervals of this section, the caliper indicates caved hole, making the lithologic log-interpretation difficult. However, the high gamma ray values coincide with intervals showing an enlarged hole, suggesting that clay-dominated intervals have caved preferentially. Further lithologic interpretation and subdivision is, therefore, suggested here on the basis of the log-motifs and cuttings samples.

2263.5-2108 $\mathrm{m}$ : The gamma ray readings reflect a sequence that coarsens upwards from sandy claystone to sandstone, but without a pronounced interbedding. 
2108-1913 and 1913-1711 m: Two upwards-coarsening sequences with significant interbedding of clay- and sand-dominated beds are indicated by the gamma ray and sonic logs. Low caliper values allow interpretation of the negative separation of the neutron-density curves as indicating an increasing number of sandstone beds in the upper part of both intervals.

$1711-1652 \mathrm{~m}$ is an upwards-coarsening and strongly interbedded interval with minor upwards-fining sequences. The lower part is dominated by claystone and the upper part by sandstone. The sandstone is probably carbonate-cemented as indicated by high sonic velocities and density values and low porosities.

$1652-1600 \mathrm{~m}$ is characterized by upwards decreasing gamma ray values, which vary significantly. Analysis of the logs and the cuttings samples suggests a claystone sequence in which the content of silt, fine-grained sand and carbonate increase upwards. Traces of anhydrite have been reported.

$1600-1292 \mathrm{~m}$ is a gradual overall upwards-coarsening and strongly interbedded series which in the upper part consists of minor upwards-fining sequences. The gamma ray readings of the uppermost approximately $50 \mathrm{~m}$ are slightly higher than in the lower part and the curve tends to have a blocky appearance. The neutron and density curves, together with the cuttings samples, show claystone and sandstone as the dominating lithologies. The number of negative separations of the neutron-density curves increases upwards.

Gassum Formation, 1292-966 m b.RT, 1254.7-928.7 m b.MSL:

The formation is here characterized by changes between low and high gamma ray values, indicating interbedding of well-defined clay- and sandstone beds. The cuttings samples show grey and dark grey colours. The upper boundary is located at an increase in gamma ray values and a decrease in sonic velocities (fig. 6). The section can be subdivided into the following three intervals, which seem to correlate with the intervals $663-511 \mathrm{~m}, 511-370 \mathrm{~m}$, and $370-297 \mathrm{~m}$ in the Hans-1 well.

In the lower part of the formation, 1292-1158 m, the gamma ray curve shows a blocky appearance, indicating interbedded claystones and sandstones. Lignite is observed in the cuttings samples. A few sonic lows may represent coaly beds or carbonaceous claystones. Generally, the sandstone intervals show log patterns indicating upwards-coarsening trends.

$1158-1075 \mathrm{~m}$ : This interval is generally characterized by higher gamma ray values than the underlying part of the formation. The high gamma ray values with a few lows indicate a claystone sequence with a few sandstone and siltstone beds.

The upper interval, $1075-966 \mathrm{~m}$, is characterized by a blocky gamma ray motif, indicating five to fifteen metres thick sandstone beds which show upwards-fining trends in the middle part and are interbedded with claystone. This interval is overlain by an upwardscoarsening sequence. Coal is common in the cuttings samples, and may be represented by minor lows on the sonic log.

Fjerritslev Formation, 966-630 m b.RT, 928.7-592.7 mb.MSL:

The formation is here characterized by rather constantly high gamma ray values, but subordinate lows are present in the upper part. The upper boundary is located at a pronounced decrease in gamma ray values, indicating the base of a sand-dominated series (fig. 6). The section can be subdivided into 5 members (see below). The interval correlates generally with the Fjerritslev Formation in more distal basin setting, but the two lower members show log features similar to those known from the Slagelse-1 and Stenlille-1 wells.

\section{F-Ia member, 966-942 m:}

The member is characterized by constantly high gamma ray values and upwards decreasing sonic velocities. The upwards decrease in gamma ray values, most commonly seen in the central part of the basin, is not present in this well. The log values and the cuttings samples suggest medium grey to dark grey claystone, and probably with subordinate siltstone interbeds. The upper boundary is located at a pronounced increase in sonic velocities.

\section{F-Ib member, $942-900 \mathrm{~m}$ :}

The high, gamma ray values slightly upwards decreasing and variable sonic velocities indicate a rather homogenous claystone sequence, probably with subordinate siltstone interbeds; according to the cuttings samples the sediments are medium grey to dark grey. The upper boundary is located at a rapid increase in sonic velocities.

F-II member, 900-858 m:

Upwards decreasing gamma ray values and constantly high sonic velocities characterize this interval, and the 
upper boundary is located at a rapid decrease in sonic velocities. Analysis of the log features and the cuttings samples suggests a sequence of silty claystone and sandstone with grey and greyish brown colours.

\section{F-III member, 858-702 m:}

The member is characterized by high, but slightly variable gamma ray values and low sonic velocities. The upper boundary is located at a decrease of the former and an increase in the latter. Analyses of the logfeatures and the cuttings samples suggest a rather homogeneous sequence of grey claystone, locally greenish or brownish grey.

\section{F-IV member, 702-630 m:}

The member is characterized by lower gamma ray values and higher sonic velocities, compared with the underlying interval. The gamma ray readings vary strongly throughout this interval. The upper boundary is located at a pronounced fall in the gamma ray values. The $\log$ features and the cuttings samples suggest a sequence of interbedded claystone, sandstone, and siltstone. Greyish colours dominate.

Haldager Sand Formation, 630-457 m b.RT, 592.7419.7 m b.MSL:

This interval is characterized by gamma readings that vary from very low to high values. The log shows blocky motifs with low values, upwards decreasing values, and thin intervals with high values. The sonic velocities are high and relatively constant compared to the overlying interval. Together with the content of the cuttings samples, these log-features indicate uniform sandstone beds interbedded with upwards-coarsening sequences and thin beds of claystone. Grey colours dominate in the coarse-grained sediments, and dark brown to black in the claystone. Lignite and coal is often present in the cuttings samples.

Flyvbjerg Formation, 457-420 m b.RT, 419.7-382.7 $m$ b.MSL:

The interval is characterized by relatively high gamma ray values at the base, decreasing to low values in the upper part, and by variable but high sonic velocities. The upper boundary is located at an increase in gamma ray values. The log features together with the cuttings samples, reflect a claystone sequence that becomes progressively interbedded with sandstones upwards.
Børglum Formation, $420-412 \mathrm{~m}$ b.RT, 382.7-374.7 m b.MSL:

This interval is characterized by high gamma ray readings, indicating a claystone sequence. The upper boundary is located at a decrease in gamma ray values and corresponding increase in sonic velocities. This thin interval is distinct from the log-motifs of the underand overlying formations and is tentatively referred to the B $\emptyset$ rglum Formation.

Frederikshavn Formation, 412-154 m b.RT, 374.7116.7 m b.MSL:

The lower half of the interval is characterized by variable, upwards decreasing gamma ray values, and the upper half by upwards increasing values. The upper boundary is located at a clear increase in gamma ray values. The gamma ray readings and the cuttings samples suggest a dark grey claystone sequence with an increasing amount of sandstone downwards.

The log-motifs suggest subdivision of the formation as follows: $412-332 \mathrm{~m}$ unit $\mathrm{A}, 332-274 \mathrm{~m}$ unit $\mathrm{B}$, and 274-154 m unit C (fig. 8).

The interpretation of the gamma ray log is slightly questionable, since it was measured through casing down to $321 \mathrm{~m}$.

Vedsted Formation, 154-109 m b.RT, 116.7-71.7 m b.MSL:

The interval is characterized by a constant gamma ray curve, with typical claystone values. The upper boundary is located at a pronounced drop in the gamma ray values. The cuttings samples indicate grey claystone.

Quaternary, 109-56.4 m b.RT, 71.7-19.1 m b.MSL (sea floor).

\section{Chronostratigraphy}

Cambrian 3363(TD)-3196 m b.RT, 3325.7-3158.7 m b.MSL:

The informal units, the quartzite and much of the "high gamma ray unit" are here referred to the Cambrian on the basis of $\log$ correlation supported by poor biostratigraphic data.

The quartzite is a similar facies as described by Hamberg (1991) from outcrops of the Lower Cambrian Hardeberga Sandstone in Scania and it is correlated with 


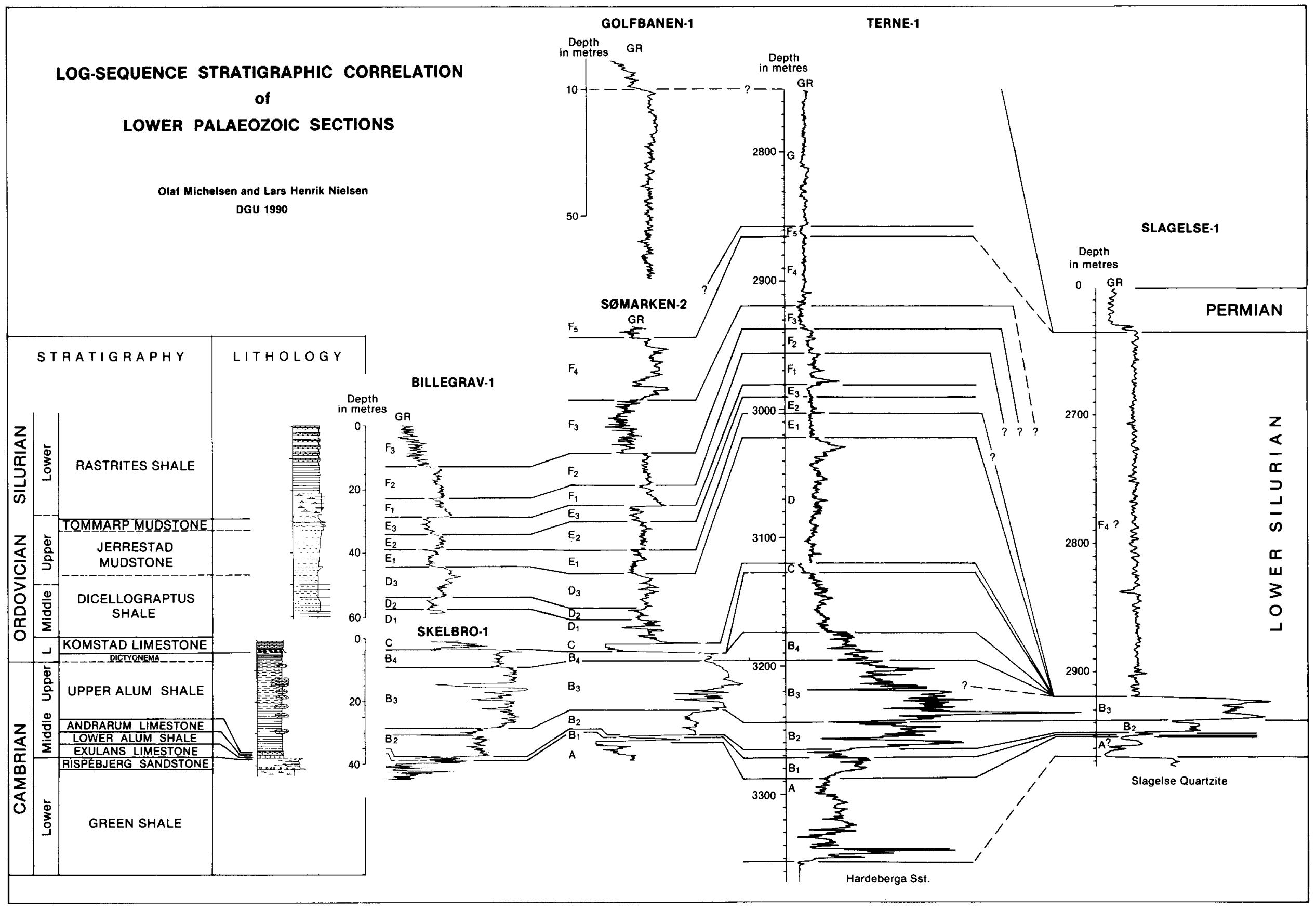

Figure 12: Correlation on the basis of log sequences of the lower Palaeozoic in the Terne-1 well with the sequences in Slagelse-1 and the shallow wells, Billegrav-1, Golfbanen-1, Skelbro-1 and Sømarken-2, on Bornholm. The log-sequences of the latter two wells and the correlation with stratigraphic units known from outcrops on Bornholm was established by Pedersen \& Klitten (1990). Note the difference in the vertical scales. 
this formation, which is regarded as a time equivalent of the Nexø and Balka Sandstones on Bornholm (Bergström et al. 1982, Gravesen \& Bjerreskov 1984).

The "high gamma ray unit" can be correlated with the Green Shales, Rispebjerg Sandstone, Exsulans Limestone, Lower Alum Shale, Adrarum Limestone, Upper Alum Shale, and Dictyonema Shale of Bornholm and the equivalent units in Scania. Comparison of the gamma ray log with the logs published by Pedersen \& Klitten (1990) indicates similar lithofacies development. The lithologic data available from the "high gamma ray unit" do not justify subdivision into the Cambrian lithostratigraphic units described from Bornholm or Scania. However, the Upper Alum shale is probably present in the upper part of this unit (fig. 12; see discussion below). Furthermore, if the correlation shown in fig. 12 is accepted, the Cambrian-Ordovician boundary may be located at approximately $3196 \mathrm{~m}$. Poor biostratigraphic data suggest that the sediments at approximately $3240 \mathrm{~m}$ are not older than Late Cambrian.

Ordovician and Silurian, 3196-2301 m b.RT, 3158.72263.7 m b.MSL:

The informal lithostratigraphic units, Dark grey to black claystone, Claystone and interbedded siltstone, and Dark grey, brownish claystone, are referred to the Ordovician and Silurian on the basis of scarce biostratigraphic data and lithostratigraphic correlation with the stratigraphic sequences known from the Scania and Bornholm.

Microplankton from a sidewall core lowermost in the dark grey to black claystone $(3158 \mathrm{~m})$, indicate an age not older than the Tremadocian, and Tremadocian forms are found higher up in the unit, at $3060 \mathrm{~m}$. The very dark colours of the claystone and the very high gamma ray values in the interval $3173.5-2938 \mathrm{~m}$, suggest a general correlation with the Ordovician-Silurian graptolite shales known from Bornholm.

The overlying claystone and interbedded siltstone unit, 2938-2744.5 m, has only yielded a few, poor biostratigraphic indicators. Analysis of the sidewall core at $2843 \mathrm{~m}$ indicated an age not younger than the Llanvirnian, whilst acritarchs found in the sidewall core at $2761 \mathrm{~m}$ suggest an Early Ludlovian age. The dark grey colour of the claystones support an overall correlation with the Ordovician and lower Silurian in Scania and on Bornholm.

Correlation with the gamma ray logs from shallow wells on Bornholm (Petersen \& Klitten (1990) show a high degree of conformity, both in log-motifs and trends (fig. 12). It is possible to correlate with the log units from Bornholm in great detail, which may lead to the conclusion that the sedimentation was controlled by the same factors in both areas. If this correlation is accepted, the Ordovician-Silurian boundary can be tentatively placed at approximately $2982 \mathrm{~m}$. This boundary will be used below, although it is not in agreement with the preliminary biostratigraphic date from $2843 \mathrm{~m}$, mentioned above.

The uppermost unit, $2744.5-2301 \mathrm{~m}$, is correlated on lithostratigraphic grounds with the Colonus shale in Scania. A cuttings sample at $2429 \mathrm{~m}$ yielded acritarchs that indicate an age not younger than Late Ludlovian; a sample from $2302 \mathrm{~m}$ suggests an age not younger than the Devonian. This would suggest a thickness of approximately $240 \mathrm{~m}$ of the Lower and Middle Silurian, which is comparable to that known from Scania (Bergström et al. 1990).

$\mathrm{K}$ - $\mathrm{Ar}$ analysis of cuttings of relatively fresh volcanic rock material selected from a cuttings sample (2459$2450 \mathrm{~m}$ ) taken in the claystone sequence yielded ages of 295 and $306 \mathrm{Ma}$, suggesting a Late Carboniferous age for the intrusive volcanic rocks.

Devonian, Carboniferous, and Rotliegendes have not been recognized as sedimentary rocks in this well. However, volcanic, intrusive rocks of Late Carboniferous age are believed present in the Upper Silurian sequence.

Zechstein 2301-2263.5 m b.RT, 2263.7-2226.2 $\mathrm{m}$ b.MSL:

Recognition of Zechstein in this well follows similar arguments to those given previously for the Hans-1 well. Palynomorphs indicating a Late Permian age were found in the interval $2297-2273 \mathrm{~m}$ b.RT. Log analysis and the cuttings samples indicate the presence of clastic sedimentary rocks. The juxtaposition of Silurian and late Permian palynomorphs indicates a major hiatus. On the seismic section (fig. 13), a thin, distinct sequence bounded by unconformities is present. The lower unconformity is very pronounced and it ties well with the major hiatus in the well. The upper unconformity is more subtle and seems to tie with the well somewhat above the interval identified as Upper Permian. As mentioned earlier, determination of the upper boundary of the Zechstein interval in the well is tentatively, because of subtle log changes. However, the accurate tie the between section in the well that contains late Permian palynomorphs and the seismic interval, which on regional seismic lines can be followed into the Zechstein of the Norwegian--Danish Basin, justify the interpretation of a clastic Zechstein deposit. 


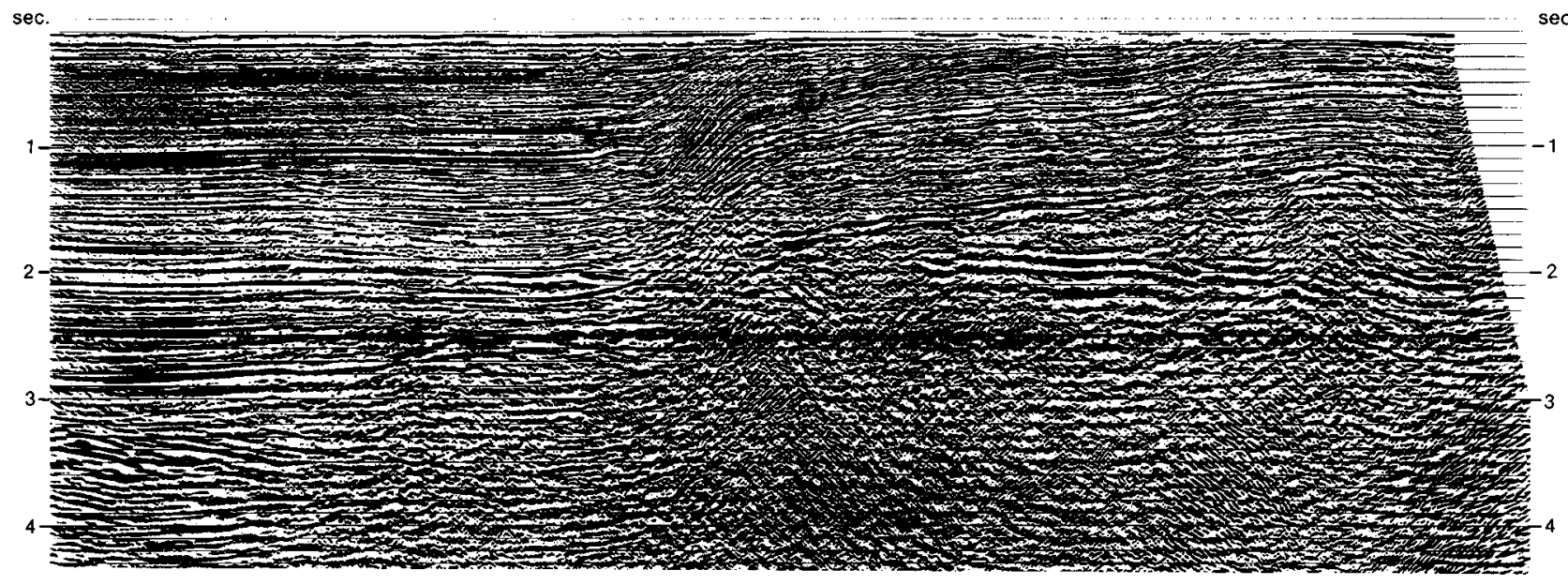

DANISH BASIN

SORGENFREI - TORNQUIST ZONE

TERNE-1

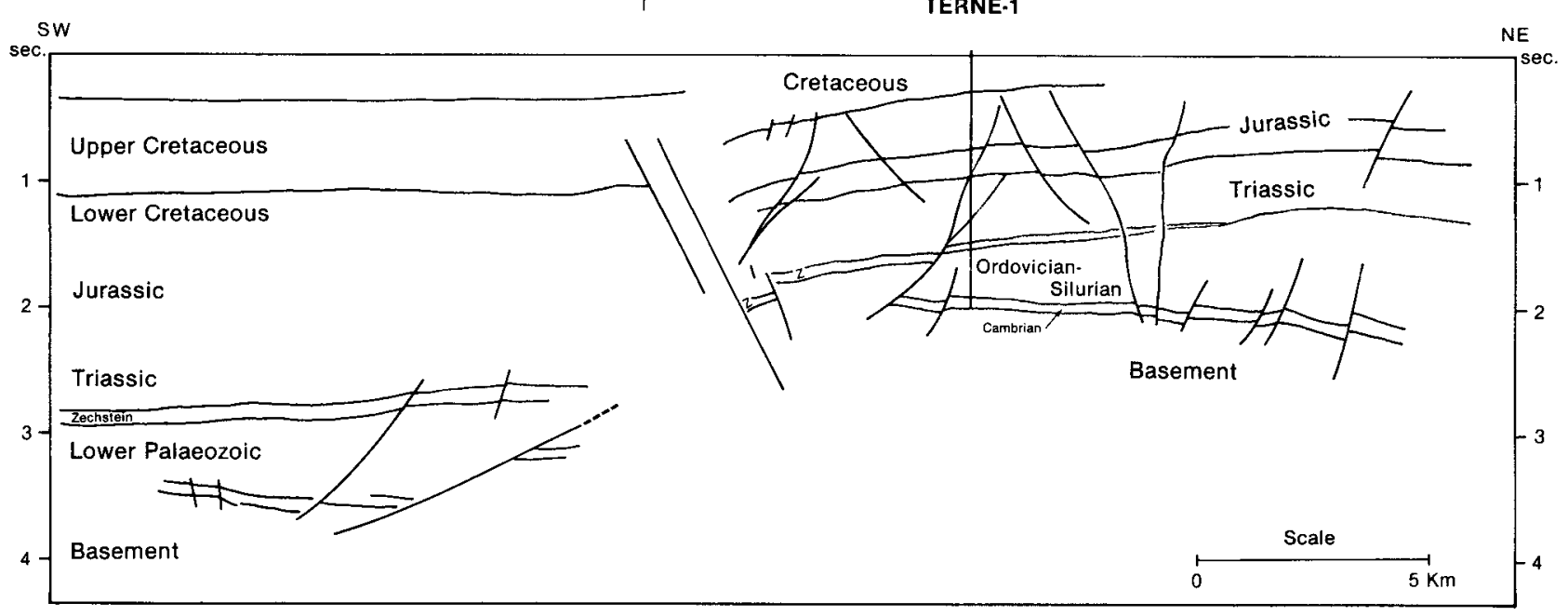

Figure 13: Interpretation of the seismic line ADK 84-117/117 A through the Terne-1 well. Location of line is shown on fig. 1.

Triassic, $2263.5-1150 \mathrm{~m}$ b.RT, $2226.2-1112.7 \mathrm{~m}$ b.MSL:

The lower Gassum Formation and the Skagerrak Formation are referred to the Triassic, which may be complete.

Based on palynomorphs the Gassum Formation interval below $1150 \mathrm{~m}$ is assigned to the Rhaetian and probably part of the Norian. The upper approximately $40 \mathrm{~m}$ are characterized by a very rich assemblage of miospores and dinocysts indicating a Late Rhaetian age. The more poorly developed assemblage in the lower part may suggest a Rhaetian-Norian age.

The Skagerrak Formation contains palynomorph assemblages of varying densities, but indicating the presence of the remaining Triassic stages.

Lower Jurassic, $1150-630 \mathrm{~m}$ b.RT, 1112.7-592.7 $\mathrm{m}$ b.MSL:

The upper part of the Gassum Formation, the F-Ia member, and the lowermost part of the F-Ib member is referred to the Lower Sinemurian-Hettangian on the basis of palynology. The top of the Lower Sinemurian is, therefore, placed approximately ten metres above the boundary of the F-1a and F-1b members; this is in accordance with previous work in the basin (Michelsen 1989b).

Poor ostracod assemblages indicate that the upper boundary of the Upper Sinemurian occurs $10 \mathrm{~m}$ below the top of the F-Ib member. Ostracod and dinocyst assemblages indicate the upper boundary of the Lower Pliensbachian is located a few metres below the top of the F-II member and that of the Upper Pliensbachian within the F-III member, at distinctive gamma ray and sonic log motifs known from other well sections (see Michelsen 1989b).

Palynomorph assemblages indicate a Toarcian (and Aalenian?) age for the upper part of the Fjerritslev Formation. The upper boundary of the Lower Jurassic is here suggested to coincide with the top of the Fjerritslev Formation on lithostratigraphic grounds. 
Middle Jurassic, $630-457 \mathrm{~m}$ b.RT, 592.7-419.7 m b.MSL:

The Haldager Sand Formation is here referred to the Middle Jurassic primarily on lithostratigraphic grounds in accordance with Michelsen (1978 and 1989a). Dinocyst and miospore assemblages show the presence of Aalenian to Lower Bathonian sediments. The upper boundary of the Lower Bathonian occurs within the overlying Flyvbjerg Formation. However, Middle Jurassic biostratigraphic indicators are restricted to the Haldager Sand Formation elsewhere in the basin and no indication of the Callovian stage has yet been found (Michelsen 1989a). The presence of Lower Bathonian palynomorphs in the Flyvbjerg Formation may be due to reworking but may also represent new important stratigraphic evidence which should be studied further (see Sæby-1).

Upper Jurassic, 457-274 m b.RT, 419.7-236.7 m b.MSL:

Ostracod and palynomorph assemblages refer the Børglum Formation and the lowermost part of unit $A$ of the Frederikshavn Formation to the Upper Oxfordian and the Kimmeridgian. The remaining part of unit $A$ and unit $B$ are referred to the Volgian.

The dinocyst species recorded at the top of unit $B$ correspond to those found in the same lithostratigraphic position by Davey (1982). This may indicate that the Jurassic-Cretaceous boundary occurs at the top of unit B.

?Lower Cretaceous, 274-109 m b.RT, 236.7-71.7 m b.MSL:

The Vedsted Formation and unit C of the Frederikshavn Formation are referred to the Lower Cretaceous on lithostratigraphic grounds. Palynomorphs recovered from this interval have ranges from Volgian to Ryazanian and are, therefore, not diagnostic.

Upper Cretaceous and Tertiary sediments have not been penetrated.

Quaternary, 109-56.4 m b.RT, 71.7-19.1 m b.MSL (sea floor). 


\section{Stratigraphy}

\section{Lower Palaeozoic}

\section{Stratigraphic correlation}

Lower Palaeozoic strata were encountered in the Terne-1 well, which penetrated the most complete lower Palaeozoic section that has been drilled to date in the Danish sector. Biostratigraphic data from this section are sparse, and of variable quality, taking into account the possibility of cavings in the cuttings samples and of reworking. Much of the biostratigraphic indicators mentioned previously are, however, from sidewall cores.

The recently published gamma ray measurements from shallow wells in the lower Palaeozoic of Bornholm (Pedersen 1989, Pedersen \& Klitten 1990) may have a significant stratigraphic potential. These logs correlate very well with the gamma ray readings from the Terne- 1 well and it is possible to identify log units with characters corresponding to those from Bornholm (fig. 12). This high degree of similarity is attributed to the widespread uniform shallow marine shelf setting that characterized both the Scania and the Bornholm region and probably also the area of the SorgenfreiTornquist Zone and adjacent parts of the Danish region to the west during much of the early Palaeozoic.

Log-readings recorded in fine-grained siliciclastic sediments reflect minor variations in composition and texture of the sediments controlled by the overall environmental conditions including, amongst other things, minor sea-level changes. It has been shown that log motifs are valuable tools in chronostratigraphic correlation (Mitchum et al. 1977, Rider 1986, Michelsen 1989 b). Major abrupt changes in the log readings, on the other hand, probably indicate the presence of hiati or diastems.

Log correlation may, therefore, represent the best tool for understanding the stratigraphy of the lower Palaeozoic succession in the Terne- 1 well. The coincidence of vertical facies development can be estimated from the two set of logs (Terne-1 and Bornholm) and it is, therefore, possible to suggest a chronostratigraphic correlation (Rider 1986, Michelsen 1989b).

Earlier in this paper, the Cambrian-Ordovician and Ordovician-Silurian boundaries in the Terne-1 well were proposed on the basis of such chronostratigraphic log correlation, whereas the Silurian-Zechstein boundary is based on lithostratigraphic evidence, supported by biostratigraphic and seismic data. In fig. 12, all the unit boundaries presented by Pedersen \& Klitten (1990) are correlated with the Terne-1 succession. It is not the intention, however, to propose precise chronostratigraphic subdivision of Terne-1. The presence of the numerous, often significant hiati in the Bornholm section makes such a precise chronostratigraphic subdivision of the Terne- 1 succession questionable. However, strata below a correlation line in one section are assumed to be older than the strata above the line in the other section. Most of the correlation lines are placed at rather abrupt changes in the gamma ray readings, indicating the presence of minor hiati.

The old Slagelse-1 well, drilled in central Sjælland, is the only other Danish well which encounters lower Palaeozoic sediments (Sorgenfrei \& Buch 1964). Detailed biostratigraphic analyses based on macrofossils from cored sections were carried out by Poulsen (1969, 1974). Poulsen referred the uppermost $170 \mathrm{~m}$ of the lower Palaeozoic sequence to one graptolite zone within the upper part of the Rastrites Shale. The underlying $85 \mathrm{~m}$ were referred to the Rastrites Shale unit on the basis of lithology. The underlying black shale sequence (Sorgenfrei \& Buch 1964) showing very high gamma ray readings was correlated with the Alum Shale. Poulsen (1969) identified a trilobite zone from a core beneath the Alum Shale; he referred that sequence to the chronostratigraphic interval between the Alum Shale and the Hardeberga Sandstone on Bornholm. The lowermost part of the well section comprises the so-called Slagelse quartzite, which was assumed to be a time-equivalent of the Hardeberga Sandstone (Poulsen 1969). Thus, the Slagelse-1 well section comprises Cambrian and Lower Silurian sequences, whereas the Ordovician apparently is absent.

Correlation of the gamma ray log from Slagelse-1 confirms the presence of a sequence equivalent to the Alum Shale (fig. 12). The Lower Silurian of the Slagelse-1 well correlates with the upper part of the Rastrites Shale equivalent in Terne-1. The $17 \mathrm{~m}$ thick sequence below the Alum Shale equivalent in Slagelse-1 may correlate with the Exsulans Limestone and the Rispebjerg Sandstone equivalent in Terne- 1 and thus the Exsulans Limestone and the Rispebjerg Sandstone on Bornholm. A one meter cored section in the middle of this interval in Slagelse-1 has been determined to the Lower Cambrian (Poulsen 1969). The gamma ray motifs of the Slagelse quartzite correlates with the Rispebjerg Sandstone equivalent in Terne-1. The two 
cored sections of Slagelse quartzite, one meter in thickness, are described as quartzite with "extremely rare" glauconite and scattered "minute crystals of pyrite" and interbedded with 5-10 m thick intervals of mudstone (Poulsen 1969). These data do not yield any basis for either correlating the Slagelse quartzite to the Rispebjerg Sandstone or the Hardeberga Sandstone on Bornholm. We prefer the latter correlation, which was also suggested by Poulsen (1969).

\section{Thickness distribution}

The recorded lower Palaeozoic succession in the Terne-1 well indicates a general increase in thickness relative to Scania and Bornholm (see table 1).

The apparent similarity of thicknesses of the Cambrian successions in Terne-1 and on Bornholm results from the fact that the Green Shale is estimated to be $100 \mathrm{~m}$ thick on Bornholm and the corresponding sequence in the well is less than $25 \mathrm{~m}$ thick. With this exception, the Cambrian-Ordovician sequence is thicker in the Terne-1 well than in the Bornholm area. The greater thicknesses observed in the well may be due to a more complete stratigraphic record. As an example, the log correlation demonstrates the presence of a sedimentary series in Terne- 1 that is not represented on Bornholm occurring between correlations of the Dictyonema Shale and the Komstad Limestone (fig. 12). Within the Ordovician succession, the thickened intervals generally occur in correlations of the shale units on Bornholm, possibly indicating that the hiati recognized on Bornholm were of less significance in the Terne-1 area.

Comparison of the Silurian thicknesses is based on the $160 \mathrm{~m}$ of Rastrites and Cyrtograptus Shales on Bornholm, 150-250 $\mathrm{m}$ of the corresponding sequences in Scania, $280 \mathrm{~m}$ in Slagelse-1, and the $250 \mathrm{~m}$ thick shale succession that underlies the volcanic series in the Terne-1 well. The younger Colonus Shale and ÖvedRamsåsa series of Scania are estimated to be at least $800 \mathrm{~m}$ thick. Time equivalent sediments are absent on Bornholm, whereas a $450 \mathrm{~m}$ thick interval of dark grey shale intercalated with volcanic rocks occur in the Terne-1 well. In both Slagelse-1 and Terne-1, the lower Palaeozoic sequence was drilled on the upthrown part of tilted fault blocks below the Permian unconformity, and seismic data indicate that a significant portion of the lower Palaeozoic is missing at both localities (e.g. fig. 13). Hans-1 was drilled on the downthrown fault block (fig. 5), and did not encounter the lower Palaeozoic. An estimate of the thickness of the lower Palaeozoic in Kattegat is thus difficult to obtain. Combining well data and seismic data, however, a maximum thickness can be estimated. At Hans-1, the TWT from the Cambrian quartzite reflector (known from Terne-1) to the TD of Hans-1 is $1280 \mathrm{msec}$. Using an average interval velocity of $5000 \mathrm{~m} / \mathrm{sec}$ as suggested by well velocity data from Terne-1 and stacking velocities at Hans-1, a thickness of the Cambrian-Silurian of $3200 \mathrm{~m}$ is obtained. In Terne-1, the thickness of the CambrianOrdovician sequence above the quartzite is $370 \mathrm{~m}$. Assuming a similar thickness in the Hans-1 area gives an apparent Silurian thickness of approximately 2830 $\mathrm{m}$. The dipmeter data indicate an average dip of $24^{\circ}$ towards the northeast; correcting for dip, the maximum Silurian thickness is approximately $2600 \mathrm{~m}$.

The chronostratigraphic position of this sequence, ranging from the Silurian-Ordovician boundary in Terne-1 to the TD in Hans-1 is not well documented. Biostratigraphic evidences from the uppermost part of the sequence in Terne-1 suggest an age not younger than the Late Ludlovian - Devonian. A few palynomorphs from the basal beds in Hans-1 are known from the Upper Carboniferous and Permian. There is no pronounced unconformity below TD in Hans- 1 on the seismic sections, that may correspond to top Silurian. The seismic reflector pattern corresponding to the lowermost sequence in Hans-1 extends 1-200 ms below TD. The thickness of the Silurian can not be further constrained and can only be stated to be less than 2600 $m$ which is in accordance with previous work (e.g. Michelsen \& Andersen 1981, Bergström et al. 1990, Vejbæk 1990).

\section{Upper Palaeozoic}

In Hans-1, a section of well-bedded clastic rocks, 254.5 $\mathrm{m}$ thick, was recorded. It is overlain by extrusive basalt beds interbedded with siltstone beds and a claystone series uppermost. This total succession is referred to the Upper Carboniferous by poor biostratigraphic evidence. It is overlain by a coarse clastic sequence including reworked volcanic rocks, corresponding to that penetrated in Sæby-1. This $550 \mathrm{~m}$ thick volcaniclastic sequence is referred to the Rotliegende on lithostratigraphic grounds. It is succeeded by Zechstein deposits.

With the exception of the $680 \mathrm{~m}$ thick section in the R-1 well situated in the Horn Graben, this represents

Table 1.: Calculated thicknesses of lower Palaeozoic successions within the Fennoscandian Border Zone

\begin{tabular}{lrlrr}
\hline System & $\begin{array}{l}\text { Terne - Hans } \\
\text { section }\end{array}$ & Slagelse-1 & Scania & $\begin{array}{c}\text { Born- } \\
\text { holm }\end{array}$ \\
\hline Silurian & max $2600 \mathrm{~m}$ & $280 \mathrm{~m}$ & $1000 \mathrm{~m}$ & $160 \mathrm{~m}$ \\
Ordovician & $192 \mathrm{~m}$ & 0 & $115 \mathrm{~m}$ & $30 \mathrm{~m}$ \\
Cambrian & $178 \mathrm{~m}$ & $50 \mathrm{~m}$ & $80 \mathrm{~m}$ & $130 \mathrm{~m}$
\end{tabular}

The Hardeberga Sandstone is not included since the base of the sandstone was not penetrated in the wells. The well data have not been corrected for structural dip. The thicknesses presented for Slagelse-1, Scania, and Bornholm are taken from Poulsen (1969 and 1974), Bergström et al. (1982), and Gravesen \& Bjerreskov (1984). 


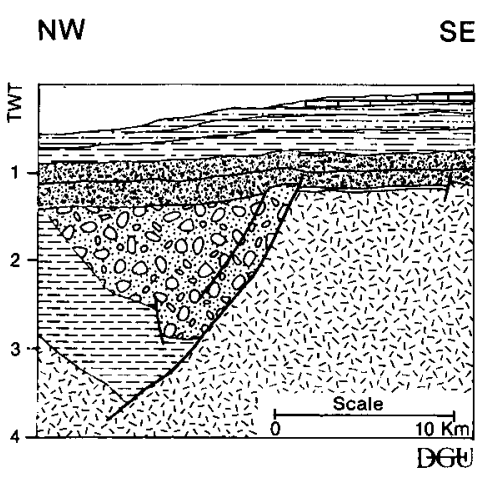

Figure 14: Geo-section from the margin of the Oslo-Bamble Trough (from Vejbæk 1990). Location is shown on fig. 1. Legend on fig. 15.

the thickest Rotliegende sequence drilled within the Danish sector. Geosections presented by Sørensen \& Martinsen (1987) indicate that the Rotliegende is typically much thinner elsewhere in the sector. However, thicknesses increase dramatically on the downthrown side of the main faults that controlled halfgraben development on the Skagerrak-Kattegat Platform and in the Sorgenfrei-Tornquist Zone. At the margin of the Oslo Graben - Bamle Trough complex a lower Palaeozoic sequence about $2 \mathrm{~km}$ thick is overlain by almost $2 \mathrm{~km}$ of presumed Upper Carboniferous - Lower Permian volcaniclastic rocks (fig. 14). Furthermore, in the tilted fault block in North Jylland north of the Børglum Fault, a thick sequence almost $1.5 \mathrm{~km}$ of volcaniclastic rocks is present (figs 10 and 15). The Sxby-1 well encountered the uppermost $200 \mathrm{~m}$ of this sequence (fig. 10). Dipmeter data in Hans-1 indicate presumed structural dips that range from $20-24^{\circ}$ at the base to $4-6^{\circ}$ towards the top of the sequence which together with the seismic data clearly indicate syn-rift deposition. Poor dipmeter data from Sxby-1 suggest a similar syntectonic sedimentation pattern.

A thin Zechstein sequence developed in a clastic facies occurs above an unconformity recognized on the seismic sections and tied in to Hans- 1 and Terne- 1 at important log-breaks. The presence of glauconite and possibly acritarchs in Terne-1 suggest a marine influence. Terne- 1 is the well located closest to the Norwegian-Danish Basin, where Zechstein carbonates and evaporites were deposited. Zechstein deposits are absent in the Sæby-1 well which is located farther away from the basin on the Skagerrak-Kattegat Platform; here the Lower Triassic onlaps Rotliegende on the hangingwell and the crystaline basement on the footwall (fig. 10).

\section{Mesozoic}

Triassic sedimentary rocks were encountered in all three wells. They comprise the Skagerrak and Gassum Formations. Palynomorphs from the younger parts of the sequences evidence the chronostratigraphic subdivision. The thickness of the Triassic varies from $536 \mathrm{~m}$ in Sæby- 1 to $1113 \mathrm{~m}$ in Terne-1 and 1187 in Hans-1. The first two of these figures are in accordance with the map published by Bertelsen (1980, fig. 3) whereas the thickness in Hans-1 exceeds the expected figure. It is worth noticing the contrast in thickness from 1113 and $1187 \mathrm{~m}$ in the Sorgenfrei-Tornquist Zone to $536 \mathrm{~m}$ on the Skagerrak-Kattegat Platform. A similar thickness change across the Børglum Fault is demonstrated by the seismic data (fig. 5).

The thickness of the Gassum Formation in Sæby-1 is $34 \mathrm{~m}$, which is close to that expected from neighbouring well data. The $300 \mathrm{~m}$ thickness of the formation in the other two wells, however, greatly exceeds the thickness previously recorded from the Danish Subbasin, although the formation is $235 \mathrm{~m}$ thick in the Lavø-1 well to the southeast, close to the Fennoscandian Border Zone.

Good lithostratigraphic and biostratigraphic evidence from the Jurassic succession allows confident correlation with wells in the Danish Subbasin. The thickness distribution and the areal extent of the lithostratigraphic units are in accordance with previous data, indicating an overall thinner succession in the Fennoscandian Border Zone compared to the Danish Subbasin. However, the $170 \mathrm{~m}$ thick Haldager Sand Formation and the $260 \mathrm{~m}$ thick Frederikshavn Formation in the Terne-1 well reflect the presence of local depocentres comparable to that drilled in the Haldager-1 well (Michelsen 1978) which is also situated in the Sorgenfrei-Tornquist Zone. It is worth noticing, that the preliminary biostratigraphy from the Sæby-1 and Terne-1 wells suggests that the hiatus between the Haldager Sand Formation and the Flyvbjerg Formation in the Danish Subbasin (Michelsen 1989) is of less significance or even absent in the Sorgenfrei-Tornquist Zone.

Lower Cretaceous deposits were encountered in the Sxby-1 and Terne-1 wells, and the Upper Cretaceous in Sæby-1. 


\section{Palaeogeographic aspects}

\section{Early Palaeozoic}

The shelf and shallow marine sedimentation patterns that are known from the Baltic region, e.g. Bornholm seem to have dominated the Kattegat part of the Fennoscandian Border Zone during the Cambrian and Ordovician. The well data, especially the gamma ray logs, allow close correlation with Bornholm, indicating a chronostratigraphic subdivision. The larger thicknesses in the study area, compared to Scania and Bornholm, apparantly reflect a more complete stratigraphic succession. The stratigraphic data do not indicate significant syn-sedimentary tectonic activity during the Cambrian and the Ordovician (see also Bergström et al. 1982 and 1990).
This depositional and structural pattern continued into the early Silurian, whereas a pronounced increase in subsidence rate (inferred from the increased sedimentation rate) is recognized to have occurred in the late Silurian in the Kattegat area. Large thicknesses of the Late Silurian Colonus Shale are known from Scania (Bergström et al. 1982). In Terne-1, the equivalent unit is $450 \mathrm{~m}$ thick and is truncated by the mid Permian unconformity (fig. 13). The Palaeozoic sequence preserved below this unconformity increases in thickness towards the main graben fault to the east (fig. 13). Farther east in the Sorgenfrei-Tornquist Zone, at Hans-1, the Silurian interval is overlain by an Upper Carbonifereous sequence. By combining well and seis-
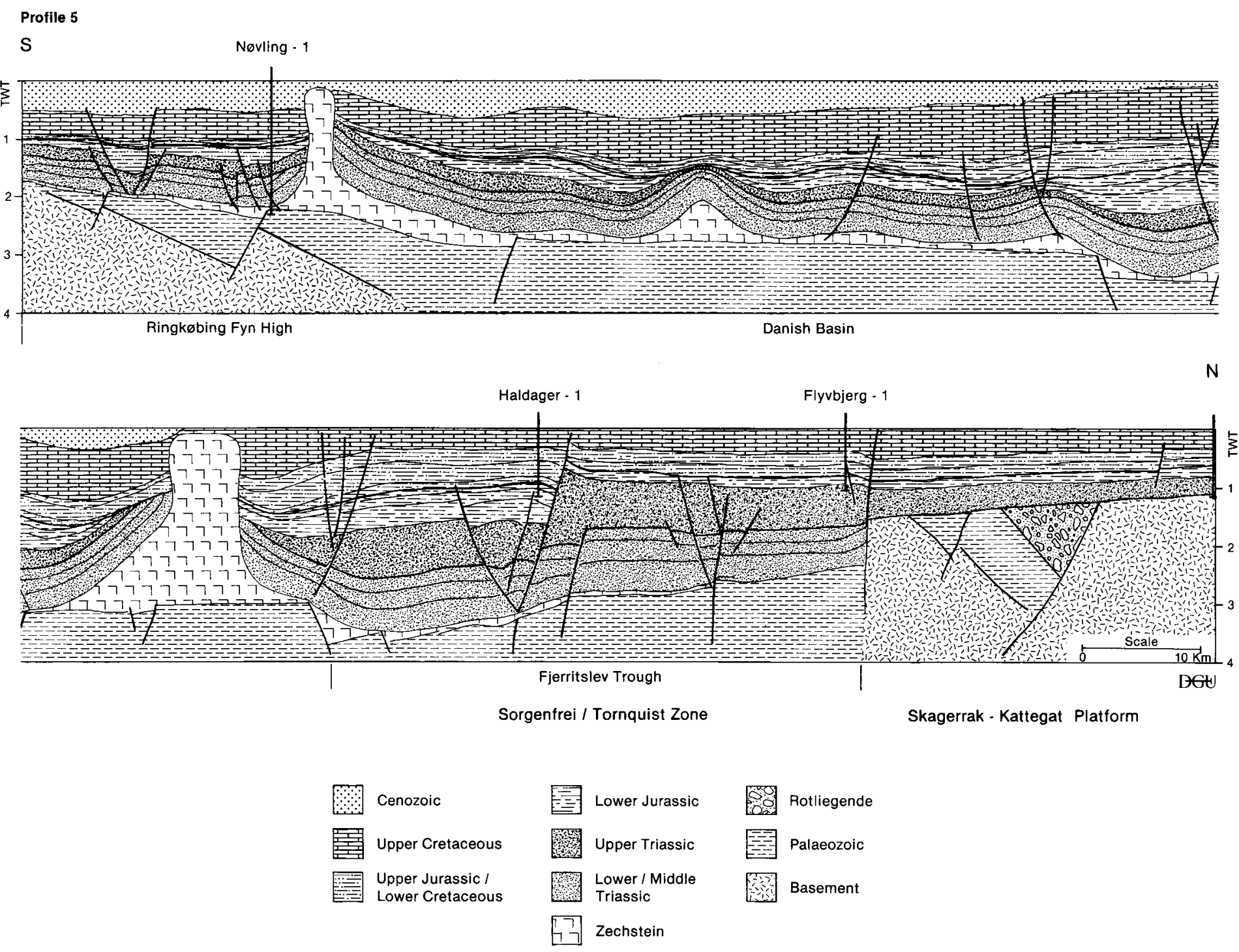

Figure 15: Regional geo-section showing the Danish Subbasin and the Fennoscandian Border Zone (from Vejbæk 1990). 
mic evidence the maximum thickness of the Silurian interval is estimated to be $2600 \mathrm{~m}$. This interval may include a thickness of strata equivalent to the Colonus Shale in Scania. The transition from the inferred $\mathrm{Co}$ lonus Shale equivalent drilled in Terne- 1 to the Rønde Formation, known from onshore wells to the west (Christensen 1971 and 1973), and to the Öved-Ramsåsa Series, known from Scania, should occur within this seismic sequence, but cannot be distinguished from the data presented here.

The stratigraphy presented here together with the seismic data show the development of a rapidly subsiding basin. However, the data available are not sufficiently detailed to determine whether 1) this fault zone was active during the late Silurian, creating a northwest trending trough (see also Bergström et al. 1982 and 1990), or if 2) the zone was part of the region that included northern Denmark, Scania and Kattegat, which acted as a rapidly subsiding foreland basin marginal to the Caledonian deformation front, south of the Ringkøbing-Fyn High (as suggested by EUGENO-S Working Group 1988). Syn-depositional tectonic activity is, however, testified by the presence of extrusive volcanic rocks in the Rønde and Nøvling Formations in the basin west of the fault zone (Christensen 1971, 1973).

In view of the clear indications that the Colonus Trough formed a syn-depositional structural element (Bergström 1984) and the presence of large sedimentary thicknesses in the Kattegat area it could be concluded that the Sorgenfrei-Tornquist Zone was an active fault zone during the late Silurian. However, continuation of the truncated Palaeozoic sequence west of the Sorgenfrei-Tornquist Zone (see fig. 13) and the presence of a thick pre-Rotliegende Palaeozoic sequence in the basin in North Jylland (fig. 15) suggest that the high Late Silurian subsidence rate also prevailed in the basin west of the fault zone. These data seem to favour the model proposed by the EUGENO-S Working Group (1988), as described above.

\section{Late Palaeozoic}

Devonian rocks were not identified in these wells and seem to be absent north of the Ringkøbing-Fyn High. Since the top of the early Palaeozoic sequence is truncated, as documented by the Terne- 1 well section and seismic data, it is not possible to determine whether sedimentation continued into the Devonian and the deposits were subsequently removed by erosion or if deposition never occurred. More than $500 \mathrm{~m}$ of marine Lower Carboniferous sedimentary rocks were drilled but not penetrated in the Ørslev-1 well, south of the Ringkøbing-Fyn High (Michelsen 1971, Bertelsen 1972). Carboniferous sedimentary rocks are also present in the Borg-1 well and possibly in the Hønning-1 well (Underwood 1988, Sorgenfrei \& Buch 1964). Marine Carboniferous deposits have been identified in the Oslo Graben by Olaussen (1981) and discussed by Bergström et al. (1985). The proposed Upper Carboniferous sequence (the "well-bedded sandstone, siltstone and claystone" unit) in Hans- 1 indicates a Carboniferous cover in the fault zone.

The occurrence of Carboniferous palynomorphs in the Jurassic sediments from Scania and on Bornholm are evidence of the presence of Carboniferous sedimentary rocks in the Jurassic source area, which probably was the Scandinavian Shield and parts of the Fennoscandian Border Zone (Guy-Ohlson et al. 1987, Guy-Ohlson \& Norling 1988, Nielsen \& Koppelhus 1991). It seems probable, therefore, that Carboniferous sediments extended over the Fennoscandian Border Zone. The missing "superficial volcanics" in Scania show that the pre-Triassic "denudation must have been very effective" in Scania (Bergström 1984). The extrusive volcanics in Hans-1 and the seismic evidence of bedded volcanic rocks farther southwest (fig. 5) may be representative of the extrusive volcanics missing in Scania. It is thought likely that the border zone subsided continously and that the volcanic series were covered by Rotliegende clastics, which locally protected them against the pre-Zechstein denudation.

Rotliegende sediments are present in the Hans-1 and Sæby-1 wells. The very thick series of Rotliegende rocks in Hans- 1 is comparable to that in the R-1 well, in the Horn Graben. However, as opposed to the Horn Graben area where Rotliegende deposition occurs prior to the rifting (Vejbæk 1990, fig. 7), deposition is clearly fault controlled in the Sorgenfrei-Tornquist Zone. Fault block tilting led to contemporaneous erosion of the footwall and deposition of volcaniclastic material on alluvial fans located on the hanging wall. Reddish siltstone clasts which occur in the Rotliegende section in Hans-1 are of a similar facies to siltstones occurring in situ deeper in the section (3031.5-2717 m), it could be argued that these testify to result from erosion on upthrown part of tilted blocks and on the footwall block. Severe pre-Zechstein erosion, both synand post-depositional, have obscured the original extent of the Rotliegende.

The recognition of siliciclastic Zechstein deposits adds significantly to our knowledge of late Palaeozoic palaeogeography. At Terne-1, the Zechstein sequence consists of dolomitic claystones and clayey sandstones, which were probably deposited in a marginal marine environment, as indicated by the presence of glauconite and possible acritarchs. Westwards, towards the basin, the interval can be followed seismically into carbonates. Towards the east the interval pinches out, reflecting the marginal position (fig. 13).

A Zechstein sequence is also identified in Hans-1. The deposits may be non-marine as no marine microfossils have been found. Interpretation of the seismic 
section suggests that the Zechstein deposition in this area occurred very locally as a result of continued subsidence along faults (fig. 5). The geo-section suggests the presence of at least one more local basin with inferred Zechstein deposits.

Tectonic activity during the late Carboniferous may be indicated by the intrusive volcanic rocks drilled in Terne-1. They are approximately time-equivalent with the earliest volcanic activity in the Oslo Graben area (Ro et al. 1990) and with the diabas dikes known from Scania where, however, only a few metres of vertical movements can be verified (Bergström et al. 1982). The extrusive volcanic rocks in Hans-1 are probably of the same age.

Differential block faulting along the Fennoscandian Border Zone is indicated by the Rotliegende volcaniclastic sequences in Hans-1 and Sæby-1 shown here to represent syn-rift sequences by the seismic data and log-data. Rifting along this fault zone seems to be contemporaneous or slightly later than rifting of the Oslo Graben as also suggested by Ro et al. (1990). This is the first phase in a series of rift events affecting the Danish North Sea region. The basin farther to the west, in North Jylland, suffered rifting during the Zechstein and the Horn Graben during the Triassic (Vejbæk 1990), whereas rift development in the Central Trough, central North Sea, occurred in the Middle-Late Jurassic.

The mid Permian unconformity records probably both syn- and post-rift erosion. The presence of a thin Zechstein clastic sequence shows that the subsidence, that caused the development of the Northern Zechstein Basin, also locally affected the Fennoscandian Border Zone.

\section{Mesozoic}

The sedimentary facies and inferred depositional environments recorded in these wells are in accordance with data known from the Danish Subbasin (Bertelsen 1978, 1980, Michelsen 1978, Michelsen (ed.) 1981). The unconformity between the Zechstein sequence and the Triassic in Hans- 1 and Terne-1 (figs 5 and 13) and the absence of Zechstein deposits at Sæby-1 suggest minor tectonic movements prior to the Mesozoic Era.

The Triassic deposits belong to the Northern Marginal Facies Province (sensu Bertelsen 1980). There is a clear difference between the thicknesses of the sedimentary sequence that accumulated on the SkagerrakKattegat Platform (Sæby-1) and in the Sorgenfrei-Tornquist Zone (Hans-1 and Terne-1), which indicates subsidence rates two to three times larger in the latter zone. It is believed that the Sorgenfrei-Tornquist Zone continued to experience tectonic activity dominated by vertical movements with subordinate strike-slip movements (Pegrum 1984, Vejbæk 1990). The thickest Triassic sequence occurs in the eastern part of the Sorgenfrei-Tornquist Zone. The stratigraphic distribution of the Gassum Formation confirms the diachronous nature of the formation, as recorded from previous wells in the Fennoscandian Border Zone (Michelsen 1975 and 1978, Bertelsen 1978).

The extreme thicknesses of the Middle Jurassic Haldager Sand Formation and the Upper Jurassic to Lower Cretaceous Frederikshavn Formation are the only anomalous features of the Jurassic sequence, as compared to those known from the Danish Subbasin. A comparable thickening of the Haldager Sand Formation is seen in the Haldager-1 well, situated farther northwest in the Sorgenfrei-Tornquist Zone. This may indicate that tectonism along the zone caused greater subsidence creating space for a thicker and more complete sequence than in the Danish Subbasin. The thickness of the Frederikshavn Formation is comparable to the thicknesses known from wells north of the Fjerritslev Fault. The formation is mainly bounded to the northeastern part of the basin, having the time-equivalent and clay-dominated Børglum Formation to the west of the Fennoscandian Border Zone (Michelsen 1989a).

The results of the Late Cretaceous and Early Tertiary tectonic inversion of the Sorgenfrei-Tornquist Zone and the subsequent erosion, described by Liboriussen et al. (1987) and EUGENO-S Working Group (1988), are evidenced by the well data. Underlying the Quaternary deposits, Lower Jurassic sedimentary rocks are found in Hans-1 and Lower Cretaceous rocks in Terne-1. Both wells are situated within this zone. In Sæby-1, on the Kattegat-Skagerrak Platform, Upper Cretaceous rocks underlie the Quaternary deposits. This variation in strata subcropping the Quaternary deposits and the structural pattern are shown by the geo-sections (figs 5, 10, and 13). 


\section{Conclusions}

Stratigraphic analysis of the three wells, in the Fennoscandian Border Zone, shows the presence of Cambrian to Silurian, Carboniferous to Zechstein, and Triassic to Early Cretaceous clastic sedimentary rocks and Late Cretaceous chalks, together with Late Carboniferous intrusive and extrusive volcanic rocks.

The Cambrian to Lower Silurian sequence can be correlated in detail with the sequence known from Bornholm and Scania and is similarly interpreted to represent shelf and shallow marine deposits. The slightly thicker sequence found in the Kattegat well, Terne-1, is suggested to represent a more complete stratigraphic sequence with less significant hiati than known from the southeastern areas. Tectonic activity during this time interval along the Fennoscandian Border Zone cannot be demonstrated.

The inferred Upper Silurian sequence is interpreted to represent deposition in a rapidly subsiding foreland basin marginal to the Caledonian front, south of the Ringkøbing -- Fyn High. The depositional environment was deep marine.

A major hiatus comprising the Devonian and the Early Carboniferous is interpreted from regional considerations, but the present data do not exclude the possibility of Devonian to Lower Carboniferous deposits within the area. The seismic sections indicate general structural conformity between the Silurian sequence and the sequence referred to Upper Carboniferous; and the hiatus mentioned above does not appear to be associated with an angular unconformity that might suggest tectonic movements.

The Upper Carboniferous clastic sequence was deposited prior to rifting. The core data indicate that the sequence was deposited in a fluvial environment.
The Late Carboniferous volcanic activity, probably heralded the rifting in the Fennoscandian Border Zone. The claystones covering the extrusive volcanic rocks (fig. 4) were probably deposited during the initial tilting. The tilting continued during deposition of more than $550 \mathrm{~m}$ of reworked volcanics and older sedimentary rocks probably on alluvial fans flanking fault scarps. The seismic section suggests truncation of extensive volcanic rocks up-dip from the Hans-1 well (fig. 5 ); a local source is also suggested by the angularity of pebbles and sand grains.

The unconformity at the base of the Zechstein deposits is most pronounced where the Rotliegende section is absent, supporting the idea of local erosion during the Rotliegende.

The Norwegian - Danish Basin subsided and was transgressed by the Zechstein sea and carbonates and evaporites were deposited. The regional rise in base level created space for deposition of a thin veneer of marginal marine to continental clastics in the Sorgenfrei-Tornquist Zone.

Before the Mesozoic, a sea-level drop may have occurred as suggested by the unconformity below the Triassic sequence and by the change in depositional environment.

The lithology and stratigraphy of the Mesozoic sequences correspond to those of the Danish Subbasin. The presence of a Middle Jurassic depocentre within the Sorgenfrei-Tornquist Zone suggest a tectonicallycontrolled local subsidence within the zone. The Late Cretaceous to Early Tertiary period of tectonic inversion, as described by earlier workers, is supported by the data presented here. 


\section{Acknowledgments}

The paper was written while Lars $\mathrm{H}$. Nielsen was in receipt of financial support from the Danish Research Academy. Colleagues at the Geological Survey of Denmark have contributed with valuable comments, and especially Claus Andersen, Kurt Damtoft, and Carsten Langtofte-Larsen are thanked. Lars Hamberg (University of Copenhagen) is thanked for comments on the interpretation of the Cambrian quartzite. Jon Ineson (Geol. Survey of Denm.), John A. Korstgård (University of Aarhus), Gunver Krarup Pedersen (University of Copenhagen), and Ole V. Vejbæk (Geol. Survey of Denm.) read the manuscript and suggested improvements. Eva Melskens made the drawings and Heinke Andersen typed the manuscript. 
Baartman, J.C. \& Christensen, O.B., 1975: Contributions to the interpretation of the Fennoscandian Border Zone. Danm. geol. Unders. II Række. 47 pp.

Bergström, J. 1984: Lateral movements in the Tornquist Zone. Geol. Fören. Stock. Förh. 106, 379-380.

Bergström, J., Holland, B., Larsson, K., Norling, E. \& Sivhed, U., 1982: Guide to excursions in Scania. Sver. geol. Unders., Ser. Ca $54,95 \mathrm{pp}$.

Bergström, J., Bless, J.M. \& Paproth, E., 1985: The marine Knabberud Limestone in the Oslo Graben: possible implications for the model of Silesian paleogeography. Z. Dtsch. Geol. Ges. 136, 181-194.

Bergström, J., Kumpas, M.G., Pegrum, R.M. \& Vejbæk, O.V., 1990: Evolution of the northwestern part of the Tornquist zone part 1. Z. angew. Geol. 36, 2, 41-45.

Bertelsen, F., 1972: A Lower Carboniferous microflora from the Årslev No. 1 borehole, island of Falster, Denmark. Danm. geol. Unders. II Rakke 99, 78 pp.

Bertelsen, F. 1978: The Upper Triassic-Lower Jurassic Vinding and Gassum Formations of the Norwegian-Danish Basin. Danm. geol. Unders. Ser. B 3, 26 pp.

Bertelsen, F., 1980: Lithostratigraphy and depositional history of the Danish Triassic. Danm. geol. Unders. Ser. B 4, 59 pp.

Christensen, O.B., 1971: Den stratigrafiske inddeling af præ-zechstein aflejringerne i Rønde nr. 1. In: Rasmussen, L.B. (ed.): Dybdeboringen Rønde nr. 1 på Djursland. Danm. geol. Unders. III Række 39, 119-123.

Christensen, O.B., 1973: Rønde og Nøvling formationerne (silur) i Nøvling nr. 1 (3534-3762 m). In: Rasmussen, L.B. (ed.): Dybdeboringen Nøvling nr. 1 i Midtjylland. Danm. geol. Unders. III Række 40, 150-157.

Davey, R.J., 1982: Dinocyst stratigraphy of the latest Jurassic to Early Cretaceous of the Haldager No. 1 borehole, Denmark. Danm. geol. Unders. Ser. B 6, 56 pp.

EUGENO-S Working Group, 1988; Crustal structure and tectonic evolution of the transition between the Baltic Shield and the North German Caledonides (the EUGENO-S Project). Tectonophysics 150, 253-348.

Gravesen, P. \& Bjerreskov, M., 1984: Guide to excursion in Born* holm. 8th annual working meeting in Sweden and Denmark of Project Tornquist/Southwest Border of the East-European Platform 1982. Danm. geol. Unders. Ser. C 3, 84 pp.

Guy-Ohlson, D., Lindquist, B. \& Norling, E., 1987: Reworked Carboniferous spores in Swedish Mesozoic sediments. Geol. Fören. Stock. Förh. 109 (4), 295-306.

Guy-Ohlson, D. \& Norling, E., 1988: Upper Jurassic Litho- and Biostratigraphy of NW Scania, Sweden. Sver. Geol. Unders. Ser. Ca 72, 37 pp.

Hamberg, L., 1991: Tidal and seasonal cycles in an Early Cambrian shallow marine sandstone (Hardeberga Formation in Scania, Southern Sweden). In: Smith, D. G., Reison, C. E., Zaithly, B. A. \& Rahmani, R. A. (eds): Clastic tidal sedimentology. Can. Soc. Petrol., Mem. 16, 255-274.

Larsen, G., 1966: Rhaetic - Jurassic - Lower Crestaceous sediments in the Danish Embayment (A heavy-mineral study). Danm. Geol. Unders. II Række 91, 127 pp.

Larsen, O., 1972: Kalium/Argon datering af prøver fra danske dybdeboringer. Dansk geol. Foren. Årsskrift for 1971, 91-94.

Liboriussen, J., Ashton, P. \& Tygesen, T., 1987: The tectonic evolution of the Fennoscandian Border Zone in Denmark. Tectonophysics 137, 21-29.

Michelsen, O., 1971: Lower Carboniferous foraminiferal faunas of the boring Årslev No. 1, island of Falster, Denmark. Danm. geol. Unders. II Række 98, 86 pp.
Michelsen, O., 1975: Lower Jurassic biostratigraphy and ostracods of the Danish Embayment. Danm. geol. Unders. II Rakke 104, $287 \mathrm{pp}$.

Michelsen, O., 1978: Stratigraphy and distribution of Jurassic deposits of the Norwegian-Danish Basin. Danm. geol. Unders. Ser. B 2 , $28 \mathrm{pp}$.

Michelsen, O. (ed), 1981: Kortlægning af potentielle geotermiske reservoirer i Danmark. Danm. geol. Unders. Ser. B 5, 96 pp.

Michelsen, O., 1989a: Revision of the Jurassic lithostratigraphy of the Danish Subbasin. Danm. geol. Unders. Ser. A 24, 21 pp.

Michelsen, O., 1989b: Log-sequence analysis and environmental aspects of the Lower Jurassic Fjerritslev Formation in the Danish Subbasin. Danm. geol. Unders. Ser. A 25, 23 pp.

Michelsen, O. \& Andersen, C., 1981: Überblick über die regionale Geologie und Tektonik Dänemarks. Z. angew. Geol. 27, 171-176.

Mitchum, Jr., R.M., Vail, P.R. \& Thompson, S., 1977: Seismic stratigraphy and global changes of sea level, part 2: The depositional sequence as a basic unit for stratigraphic analysis. In: Payton, Ch.E. (ed.): Seismic stratigraphy - applications to hydrocarbon exploration. The Amer. Ass. Petr. Geol., Mem. 26, 53-62.

Nielsen, L.H. \& Koppelhus, E.B., 1991: Reworked Carboniferous palynomorphs from the Lower Jurassic of Bornholm and their palaeogeographic significance. Bull. geol. Soc. Denmark, 38, 253 266.

Olaussen, S., 1981: Marine incursion in Upper Palaeozoic sedimentary rocks of the Oslo region, southern Norway. Geol. Mag. 118, 281-288.

Pegrum, R.M., 1984: The extension of the Tornquist Zone in the Norwegian North Sea. Norsk Geologisk Tidsskrift 64, 39-68.

Pedersen, G.K., 1989: The sedimentology of Lower Palaeozoic black shales from the shallow wells Skelbro 1 and Billegrav 1, Bornholm, Denmark. Bull. geol. Soc. Denmark 37, 151-173.

Pedersen, G.K. \& Klitten, K., 1990: Anvendelse af gamma-logs ved korrelation af marine skifre i vandforsyningsboringer på Bornholm. Dansk geol. Foren., Årsskrift for 1987-89, 21-35.

Poulsen, C., 1969: The lower Cambrian from Slagelse No. 1, Western Sealand. Danm. geol. Unders. II Rakke 93, 29 pp.

Poulsen, C. 1974: Further contributions to the knowledge of the Palaeozoic of Slagelse No. 1, Western Sealand. Danm. geol. Unders., II Række 101, 72 pp.

Rider, M.H., 1986: The geological interpretation of well logs. Blackie, Glasgow and London, $175 \mathrm{pp}$.

Ro, H.E., Larsson, F.R., Kinck, J.J. \& Husebye, E.S., 1990: The Oslo Rift -- its evolution on the basis of geological and geophysical observations. Tectonophysics, 178, 11-28.

Sorgenfrei, T. \& Buch, A, 1964: Deep tests in Denmark, 1935-1959. Danm. geol. Unders. III Rakke 36, 146 pp.

Sørensen, S. \& Martinsen, B.B., 1987: A palaeogeographic reconstruction of the Rotliegendes deposits in the Northeastern permian Basin. In: Brooks, J. \& Glennie, K. (eds): Petroleum Geology of North West Europe. Graham \& Trotman, 497-508.

Underwood, J., 1988: 5508/32-2 (Borg-1) Danish onshore well: Biostratigraphy of the interval $10 \mathrm{~m}-3080.2 \mathrm{~m}$ TD. The Robertson Group plc., Report No. 3862/Ia.

Vejbæk, O.V., 1990: The Horn Graben and its relationship to the Oslo Graben and the Danish Basin. Tectonophysics 178, 29-49.

Ziegler, P.A., 1982: Geological atlas of Western and Central Europe. Shell International Petroleum Maatschappij, The Hague. Elsevier, Amsterdam, $130 \mathrm{pp}$. 


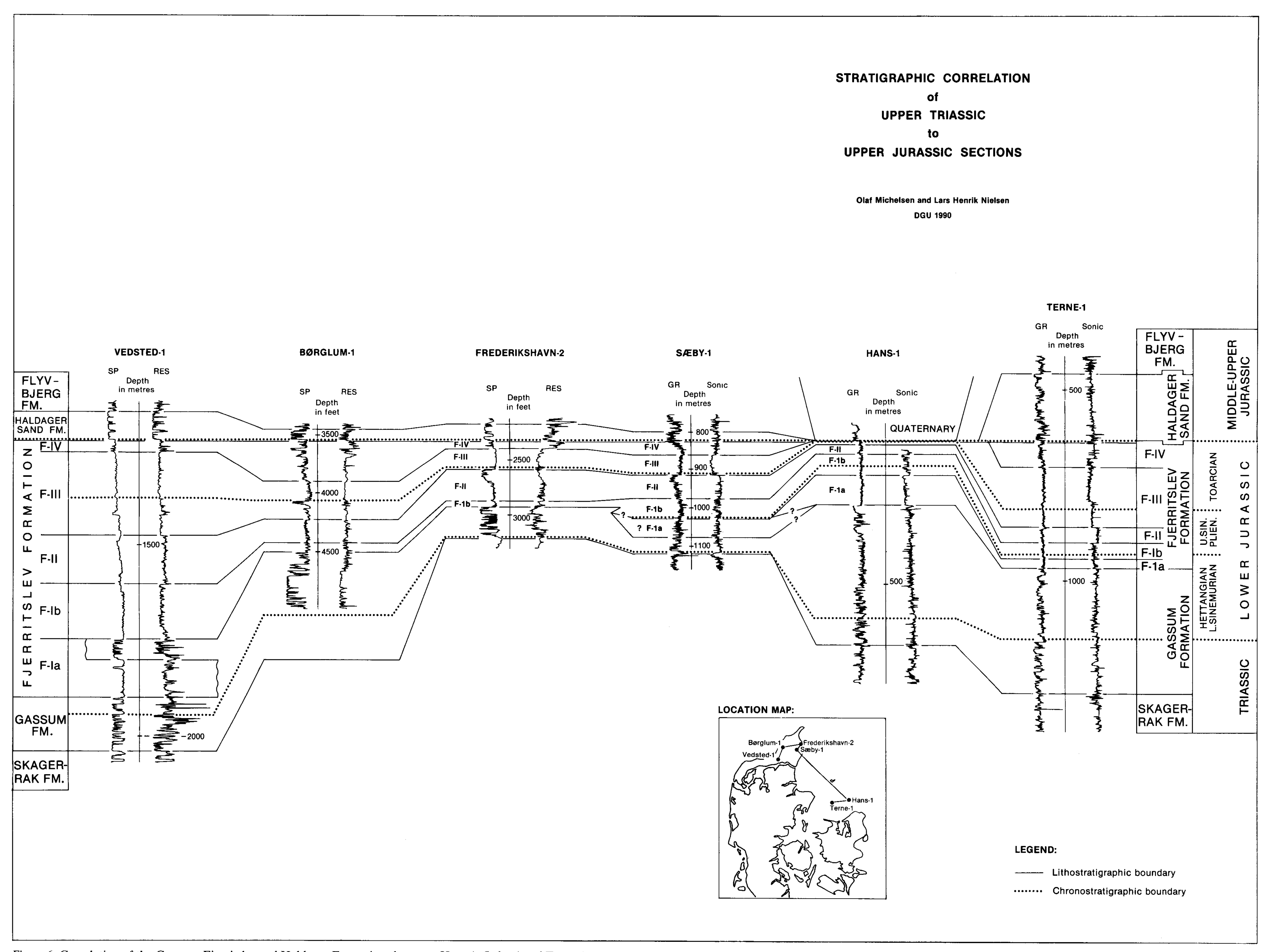

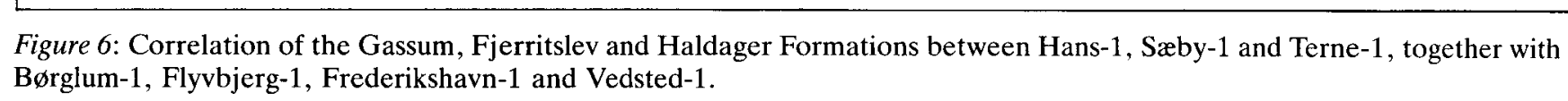


This paper comprises a presentation and interpretation of data from the first deep wells (Hans-1, Terne-1) within the Kattegat segment of the Sorgenfrei-Tornquist Zone. The Saby-1 well, located on the SkagerrakKattegat Platform is also included in the study. The wells encountered Cambrian to Silurian, Upper Carboniferous to Zechstein, and Mesozoic sedimentary rocks. Furthermore, Upper Carboniferous extrusive and intrusive volcanic rocks were penetrated. 